\begin{tabular}{|l|l|}
\hline $\begin{array}{l}\text { 2. To: (Receiving organization) } \\
\text { Distribution }\end{array}$ & $\begin{array}{l}\text { 3. From: (Originating Organization) } \\
\text { Characterization Equipment } \\
\text { Design }\end{array}$ \\
\hline $\begin{array}{l}\text { 5. Proj./Prog./Dept./Div.: } \\
\text { W75230/N4H2A }\end{array}$ & $\begin{array}{l}\text { 6. Cog. Engr.: } \\
\text { G.P. Janicek/R/P. BTanchard }\end{array}$ \\
\hline B. Originator Remark: &
\end{tabular}

Release. This is the third report on this subject.
4. Related EDT No.:

615401

7. Purchase Order No.:

$$
\text { N/A }
$$

9. Equip./Component No.:

$$
\text { N/A }
$$

10. System/Bldg./Facility: 200 General

11. Receiver Remarks:
12. Major Assm. Dhg. No.:

$$
\text { N/A }
$$

13. Permit/Permit Application No.: $\mathrm{N} / \mathrm{A}$

14. Required Response Date:

$N / A$

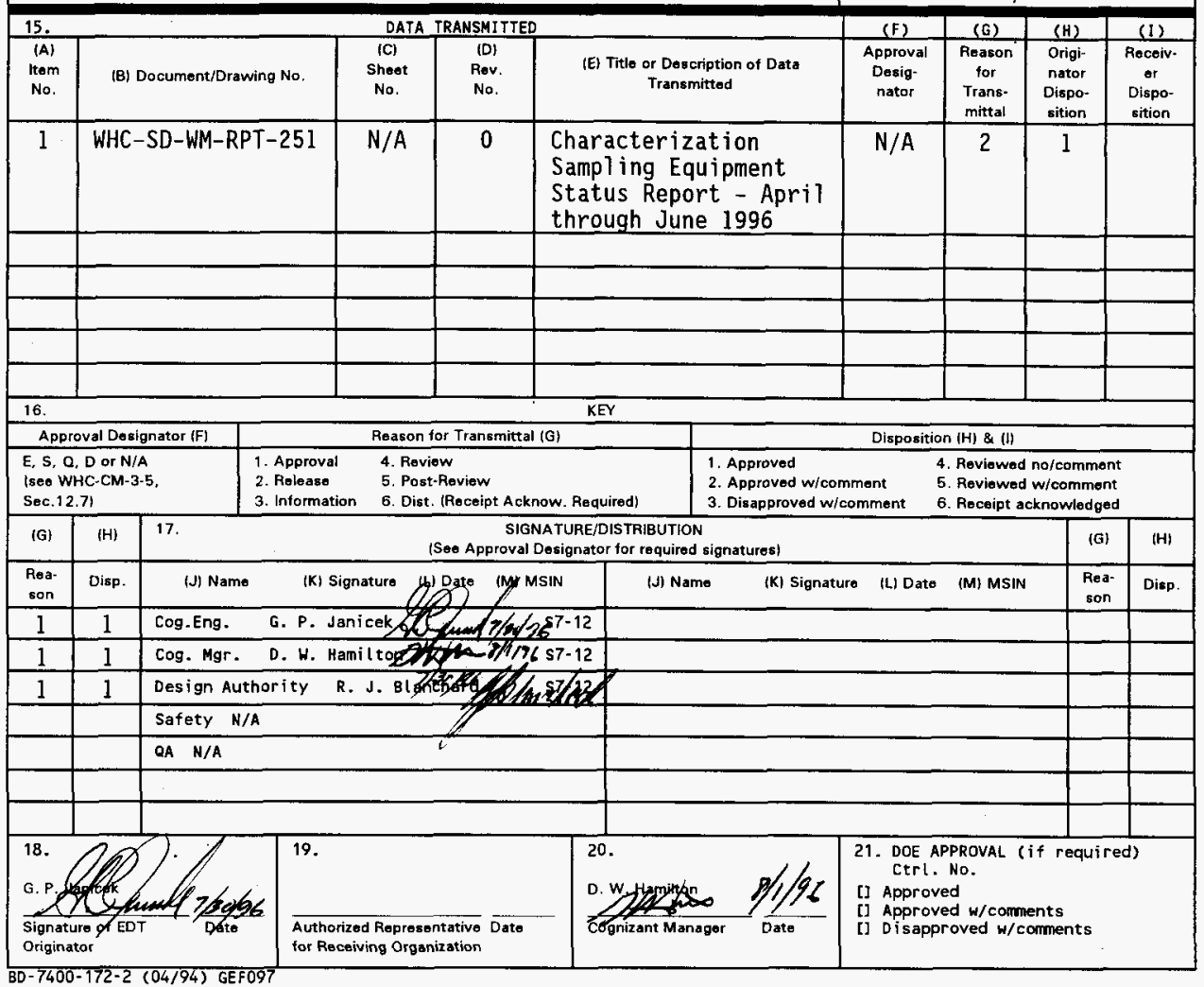




\title{
Characterization Sampling Equipment Status Report - April through June 1996
}

\author{
G. P. Janicek and R. J, B Tanchard
}

Westinghouse Hanford Company, Richland, WA 99352

U.S. Department of Energy Contract DE-AC06-87RL10930

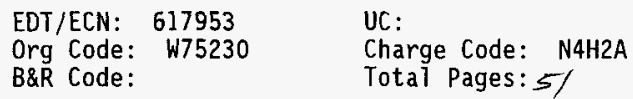

Key Words: Characterization, Sampling Equipment, Samplers, Equipment Improvement, RMCS, Availability, Reliability, Core Sampling Trucks

Abstract: This report is the third status report on Characterization Sampling Equipment. It covers April through June 1996 activities. Subsequent reports are intended to be issued quarterly.

The degree of success in sample recovery and in the availability of equipment to take samples is reported on as are the measures being taken to track and improve recovery and availability. Planned activities are also presented.

TRADEMARK DISCLAIMER. Reference herein to any specific commercial product, process, or service by trade name, trademark, manufacturer, or otherwise, does not necessarily constitute or imply its endorsement, recommendation, or favoring by the United States Government or any agency thereof or its contractors or subcontractors.

Printed in the United States of America. To obtain copies of this document, contact: WHC/BCS Document Control Services, P.0. Box 1970, Mailstop H6-08, Richland WA 99352, Phone (509) 372-2420; Fax (509) 376-4989.
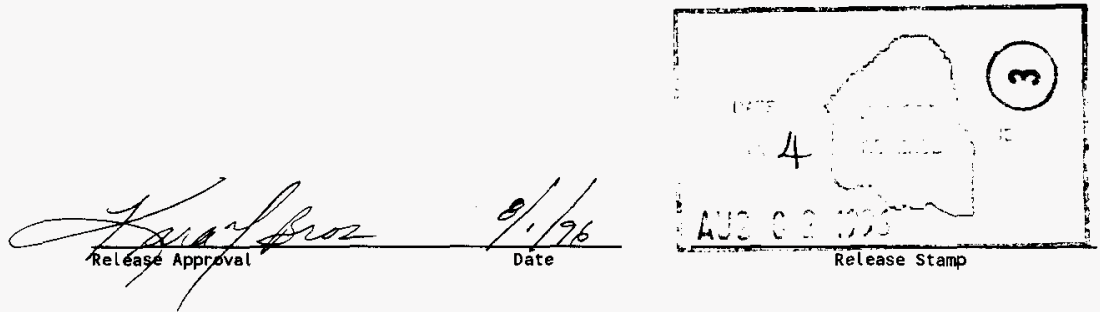

\section{Approved for Public Release}




\section{WHC-SD-WM-RPT-251 \\ Revision 0}

Prepared By:

R.J. Blanchard

G.P. Janicek

WESTINGHOUSE HANFORD COMPANY

JULY 1996 


\section{CHARACTERIZATION SAMPLING EQUIPMENT STATUS REPORT APRIL THROUGH JUNE 1996}

\section{CONTENTS}

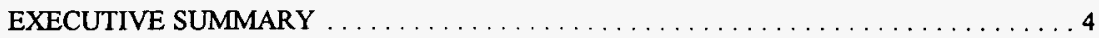

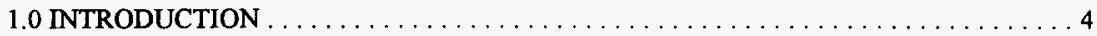

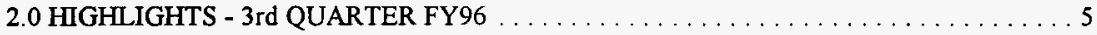

2.1 IMPROVING SAMPLE RECOVERY $\ldots \ldots \ldots \ldots \ldots \ldots \ldots \ldots \ldots$

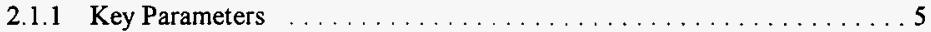

2.1.2 Data ................................ 6

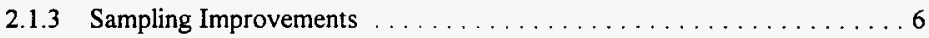

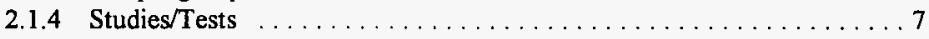

2.1 .5 Evaluations . . . . . . . . . . . . . . . . . . . . . 9

2.2 EQUIPMENT AVAILABILITY/RELIABILITY IMPROVEMENTS $\ldots \ldots \ldots 9$

2.2.1 Equipment Development . . . . . . . . . . . . . . . . . .9

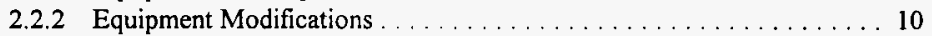

2.2.3 Management of Equipment Problems ................. 11

2.2.4 Equipment Problem Analysis/Corrective Actions . . . . . . . . . . . 13

2.2.5 Availability/Reliability Evaluations . . . . . . . . . . . . . . 13

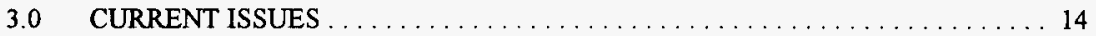

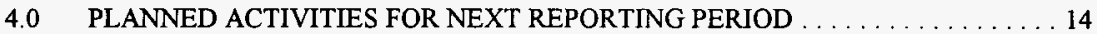

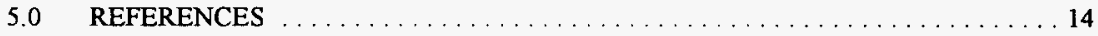

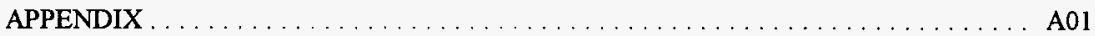


WHC-SD-WM-RPT-251

Rev. 0

\section{CHARACTERIZATION SAMPLING EQUIPMENT STATUS REPORT APRIL THROUGH JUNE 1996}

\section{EXECUTIVE SUMMARY}

Characterization Equipment Engineering (CEE) still continues to make significant progress towards the project goals of Characterizing the Hanford High Level waste tanks. Four systems were operational during this reporting period, three Rotary-mode core sampling truck systems and one push-mode truck system.

As noted in the last report, the planned efforts outlined in Engineering Task Plan, WHCSD-WM-ETP-159, "Improving Sampling Recovery, Engineering Task Plan" (Blanchard 1995) for this reporting period have been delayed. This was done to support the testing efforts required to document the safety concerns noted in the Safety Assessment (SA) of Rotary Mode Core Sampling in Flammable Gas Single Shell Tanks: Hanford Site, Richland, Washington, WHC-SD-WM-SAD-035, Revision 0.

The availability average for the Core Sampling Systems for this quarter is 69\%, including the unavailability of Truck System \#4 for four (4) weeks due to outage time required for upgrading the truck for Flammable gas sampling. Excluding the flammable gas upgrade outage time, the overall Core Sampling System availability was $72 \%$, the same as reported last quarter.

It is noteworthy, that Characterization Equipment Engineering achieved the 65\% availability goal as of the end of the 3rd quarter, including the Flammable gas upgrade outage. 


\subsection{INTRODUCTION}

The purpose of this report is to status the activities and plans for improving sampling recovery and equipment availability/reliability. The reports are meant to be the library of facts for CEE deliverables to Characterization Project.

\subsection{HIGHLIGHTS - 3rd QUARTER FY96}

This report statuses the activities and plans accomplished by CEE for the period from April 1, 1996 through June 30, 1996.

\subsection{IMPROVING SAMPLE RECOVERY}

All planned activities associated with improving sample recovery were canceled due to the large efforts needed to support the ignitability testing and bit temperature testing. The funding for the support of the "Tank Sampling Assistance Panel" (TSAP) was needed to support the safety assessment and testing and this made it necessary to cancel all TSAP planned activities for this fiscal year.

\subsubsection{Key Parameters}

During this quarter, three rotary-mode truck systems, and one push-mode system actively sampled waste in the Hanford waste tanks.

\begin{tabular}{|c|c|c|}
\hline Truck Number & Obtained Samples from... & Riser Number \\
\hline 1 (Push Mode) & Tank 241-AW-101 & $24 \mathrm{~B}$ \\
\hline 1 (Push Mode) & Tank 241-AN-105 & $12 \mathrm{~A}$ and 7B \\
\hline 2 & Tank 24l-S-101 & $\mathbf{1 1}$ and 14 \\
\hline 2 & Tank 241-S-111 & 14 \\
\hline 2 & Tank 24l-S-109 & 19 and 2 \\
\hline 3 & Tank 24l-U-102 \\
\hline 3 & Tank 24l-U-106 & $10 \mathrm{~A}$ \\
\hline 3 & Tank 241-U-107 & 7,9 and 2 \\
\hline 3 & Tank 24l-BY-102 & \\
\hline 4 & Tank 241-U-108 & 19 \\
\hline
\end{tabular}


WHC-SD-WM-RPT-251

Rev. 0

During this quarter 174 samples were obtained, Trucks 2, 3 and 4 obtained 104 samples and Truck \#1 obtained 70 samples.

\subsubsection{Data}

Color profiles of the extruded samples are on file in CEE, as well as in the 222-S laboratory. CEE developed a colored "Core Sample Extrusion Template" see figure A01. This template is used by the laboratory and others to describe the sample medium as noted an the template, which adds to the understanding and provides an common description for the samples.

\subsubsection{Sampling Improvements}

Due the concerted efforts needed to support the Ignitability Testing and Bit Temperature Testing efforts planned towards sampling improvements noted in WHC-SD-WM-ETP-159, "Improving Sample Recovery, Engineering Test Plan" were canceled until fiscal year 1997. During this period a total of 46 individual core segments were X-rayed as requested by operations.

X-Ray Imaging System XRI-004 was brought out of field service prior to its semi-annual date to repair a faulty internal standards manipulator. On May 8, 1996 after the service was complete an accident occurred while the system was being hooked to a towing vehicle on which the hitch was located 34.25 inches from the ground. A slight bump of tractor caused the XRI system flip over, spilling the contents of the X-ray cooling system (ethylene glycol) and 13 gallons of the insulating oil (Shell, DIALA-R, AX) from the damaged high voltage generator. An OffNormal Occurrence Report (RL--WHC-GENERAL-1996-008) was prepared.

The X-ray power supply and high voltage tank and the image intensifier were returned to the vendor for repair and re-calibration. The internal lead shutters on the $X$-ray tube were replaced. Repair and replacement of damaged components was completed during the third week of June. System XRI-004 is currently in use for Retained Gas Sampler (RGS) sample segments in 241A Tank farm.

System XRI-003 semi-annual service was scheduled to completed on July 7, 1996 and be ready to be returned to the field. System XRI-002 six month service date (6/1) was extended for 30 days with the concurrence of the Radiological Control Organization. The system will also have the sealants and exterior safety switch installed to address flammable gas issues. System XRI-001 will be removed from the field for semi-annual service at the end of July.

A demonstration of a linear diode array $\mathrm{X}$-ray imaging device was performed during June. This digital device was temporarily installed in XRI-004 directly in front of the image intensifier face- 
plate. This device directly produces a digital X-ray image which can be printed as being acquired in a full length, full size image of the sample segment (approximately 24 inches long). This equipment can be installed as an up-grade to the XRI systems. The vendor has informally been requested to provide an approximate cost estimate (ROM) for the installation of the up-grade.

\subsubsection{Studies/Tests}

The testing efforts required to support the safety assessment activities were conducted per WHC-SD-WM-TP-411, Revisions 0 and 1, "Test Plan for Core Drilling Ignitability Testing" at the U.S. Bureau of Mines, Pittsburgh, Pa. The test results are documented in WHC-SD-WMTRP-257, "Core Drilling Ignitability Testing", Revision 0. The purpose of the testing noted above was to determine if an ignition of flammable gasses would occur while core sampling. Many different dynamic processes occur while sampling, but only a limited number of these which have a direct bearing on the flammable gas ignition issue required testing. The dynamic processes of interest can be generally categorized as follows:

- What ignition hazard of the sampling bit/waste interface exists while rotary drilling?

- What ignition hazard of the drill string/riser tube interface exists while rotary drilling?

- What ignition hazard of the sampler and associated ancillary equipment within the drill string exists before, during, and after a sample is obtained?

Note that each of these items involve drilling equipment which can make direct contact with the flammable gas mixture found in some of the waste tanks.

The above categories were further broken down into the following six ignition questions which the testing was designed to address:

1. Will an ignition of a flammable gas occur while drilling into rock in a waste tank?

2. Will an ignition of a flammable gas occur while drilling into a steel object in a waste tank?

3. Will an ignition of a flammable gas occur after an accidental drop of sampler and the subsequent impact onto the internal surface of the drill bit?

4. Will an ignition of a flammable gas occur after an accidental drop of the Remote Latching Unit and subsequent impact onto a sampler?

5. Will and ignition of a flammable gas occur during an impact caused by a misalignment of the Quill Rod Adapter and drill string?

6. Will an ignition of a flammable gas occur during frictional rubbing of the drill string against a steel riser? 
Each item tested was identical to warehouse stock used in normal drilling operations. Some of the items tested required modifications during testing, and therefore the final modification made to the item became the new standard design to be used for field sampling operations.

Additional testing was performed and documented in WHC-SD-WM-TRP-252, Revision 0, "Standard Rotary Bit Temperature Testing". This testing program was a joint effort between Westinghouse Hanford Company, CEE and Los Alamos National Laboratory (LANL). Testing was requested by LANL in support of safety assessment preparation activities noted above. The testing program noted in the report was a very flexible in that daily inputs were received from LANL. Therefore an informal test plan was used as the basis for initial test activities. This testing helped establish the equipment parameters required to safely rotary drill.

\subsubsection{Evaluations}

All core sampling during this period was done in push mode, no drill string rotation was used. Core profiles for each tank sampled are shown in figures A02 Through A11. Trucks \#2, \#3 and \#4 obtained 104 samples during the period and truck \#1 obtained 70 samples. Recovery percentages are calculated per Internal Memo, 75210-016-95-4, "Sample Recovery Measurement Parameters" dated June 24, 1996.

Truck \# 1 completed three cores on two double-shell tanks with very deep waste (22 segments each), the 2nd of two cores on AW-101 and both cores on AN-105. Average recovery on AW101 was an outstanding 95\%. Similarly, recovery averaged in excess of $92 \%$ on AN-105. Waste conditions in both tanks were very soft. Tank AN-105 will be discussed further in the subsequent quarterly report when details of the 2 nd core become available. Twelve Retained Gas Samples were successfully captured using this system during the period. Figure A12 documents the performance of truck \#1 thus far in FY 1996

The tanks which follow were all sampled with the rotary mode systems, trucks \#2, \#3, and \#4. Figure A13 indicates the performance of the rotary systems from October 1995 through June 1996. A dramatic improvement in sample recovery is apparent in Figure A13 during late March. This improvement is due directly to changes in the sampler configuration and sampling process. Average recovery for samples obtained during the quarter was an impressive $84 \%$, a $42 \%$ improvement from that of the previous quarter.

The final of three cores was obtained from tank S- 101 during April. Average recovery was $41 \%$ for the first two cores, but recovery improved to $94 \%$ on the final core of this tank. Of significance is the fact that the eight segments of the final core on S-101 were completed in a single day, demonstrating the ability of the rotary mode equipment and personnel to excel when conditions are favorable. The waste encountered in S-101 was very soft, penetration forces 
remained below 500 pounds on nearly all segments.

Three cores including 30 samples were taken on tank U-108 between April and mid May. Performance was very good, averaging $83 \%$. The waste in U-108 was relatively soft, seldom did waste penetration forces exceed 1000 pounds.

Tank U-102 was sampled in late April. Sample recovery was outstanding, averaging $87 \%$ for the 16 samples obtained between the two cores. Waste conditions were relatively soft in the upper half, requiring only 1000 pounds of penetration force. A hard layer was encountered on both sides of the tank on the 3rd segment from the bottom. Partial penetration of the layer was achieved, however at 2800 pounds the drill string buckling limit prevented further waste penetration.

Sampling on tank U-106 was very successful during mid May. Sample recovery ranged between $72 \%$ and $100 \%$ on all 10 samples from the two cores obtained. Average recovery was $90 \%$ on this tank. All samples were obtained in 3 consecutive days, a significant event considering that the truck was relocated on the tank between the two cores. This accomplishment once again demonstrates advancements in the core sampling process. The waste encountered in U-106 was very soft, penetration forces remained below 500 pounds on all segments.

Tank S-111 was sampled in late May and early June. Two cores were attempted. The 11 segments of first core were completed successfully, requiring 2000 pounds to penetrate near the tank bottom. An impenetrable layer was encountered on the 3 rd of 11 segments of the 2 nd core. Several techniques were attempted including pushing almost 4000 pounds to break through the layer, with very limited success. Recovery was very good despite the waste penetration resistance, averaging $89 \%$ for all 18 samples taken.

One core was successfully captured with little waste penetration resistance from BY-107 in early June. Average recovery for the 5 segments was $86 \%$. The second scheduled core for this tank was postponed until July due to changing priorities. This tank will therefore be discussed further in the subsequent quarterly report.

The first of two scheduled cores was attempted on tank BY-102 in late June. A hard layer requiring almost 2000 pounds to penetrate was encountered half-way through the 8 segments of the first core. A second hard layer was encountered, halting waste penetration, at the start of the final segment of this core. Recovery of the dry saltcake was good despite the significant waste penetration resistance, averaging $64 \%$ for all samples. This tank will be discussed further in the subsequent quarterly report when information becomes available on the 2 nd core.

Tank S-109 was the final location for sampling activity during the period. Seven samples were 
obtained from a single core. Recovery was very good in the dry saltcake, averaging almost $80 \%$, however a hard layer was encountered about one third of the way to the tank bottom, preventing full penetration in push mode with 4000 pounds. This tank will be discussed further in the subsequent quarterly report when information becomes available on the 2 nd core.

\subsection{EQUIPMENT AVAILABILITY/RELIABILITY IMPROVEMENTS}

Equipment currently available to the Characterization Project for obtaining samples of wastes from underground tanks includes vapor samplers, grab samplers, auger samplers, and core samplers. The vapor, grab, and auger samplers are relatively simple devices and are easily deployed in the field with minimal attendant equipment. Core samplers require in-tank insertion by a complex, special-built drill rig truck with its own contingent of support equipment, which could include, for example, an exhauster, a diesel generator, electrical distribution and nitrogen supply trailers, a breathing air compressor, etc. A core sampling system (CSS) entails a much more complex operation and has a greater potential to adversely impact Characterization Project objectives and schedules. For this reason a CSS is the primary focus of equipment availability/reliability improvements. The approach to improving equipment availability and reliability is documented in an Engineering Task Plan (Janicek 1995).

\subsubsection{Equipment Development}

Characterization Operations has had in its inventory, since July 11, 1995, four CSSs: truck system \#1, capable only of push-mode core sampling, and truck systems \#2,\#3,\#4 capable of both push- and rotary-mode core sampling, each using the universal core sampler. Truck system $\# 1$ was acquired for use first, followed by truck system $\# 2$ in order to add rotary-mode capability, and then in 1995 truck systems \#3 and \#4 were added simultaneously to improve overall sampling equipment availability. Each truck system comprises the drill-rig truck itself and all necessary supporting equipment. The individual truck systems are depicted in cartoon fashion in Figures A14, A15, A16 \& A17. Truck system \#1 component equipment is configured differently than truck system $\# 2$, and both $\# 1$ and $\# 2$ are configured differently than $\# 3$ and $\# 4$, reflecting the design evolution of the sampling trucks, themselves. For reasons of safety, reliability, and availability, as discussed in the last Quaterly Report (reference req'd) there has been an ongoing attempt to revise truck system $\# 1$ and $\# 2$ configurations to match that of $\# 3 / \# 4$. As reported then, the acquisition of one (1) additional generator (for truck system \#1) and two (2) additional electrical distribution trailers (for truck systems \#1 and \#2) was being pursued. The generator has been delivered and is now part of truck system \#1 (G-A, in Figure A14). Regarding the two electrical distribution trailers, being fabricated onsite, the one for truck system $\# 1$ is nearing completion and the one for truck system $\# 2$ has been put on-line (DT-B, in Figure A15). 
During this reporting period the Exhauster for truck system \#4 (EX-C, in Figure Al7) has been undergoing extensive modifications to make it intrinsically safe for exhausting flow-through air (and generated gases) from flammable gas, watchlisted tanks. The modification has required the procurement of a special Flammable Gas Detection System to monitor for flammable gas conditions and to shutdown sampling operations should set-point threshhold levels for certain gases be detected. This was being done for truck system \#4 during this reporting period, because truck \#4, itself, is the first to be undergoing flammable gas modifications (see Section 2.2.2, below). Full implementation of this system is expected during the next reporting period. Procurement of similar systems for trucks \#2 and \#3 is planned.

\subsubsection{Equipment Modifications}

As reported in the past, the acquisition of truck systems \#3 and \#4 was accomplished using design drawings from truck system \#2 and making minimal changes thereto, so as to expedite the acquisition. This resulted in a list being generated of known modifications to sampling trucks \#2, \#3, and \#4 that would improve their operational reliability, but which would have to wait to be implemented during future maintenance outages. Operational experience has seen a growth in the number of items on this list. Figure A18 depicts a listing of thirteen (13) of the more visible modifications planned and their status, updated from the previous reporting period, as regards each of the four trucks.

In addition to reliability modifications, modifications to improve safety, operability, maintainability, availability (as a result of operational and field problem experience), and those required to satisfy the safety assessment of rotary-mode operation in flammable gas watchlist tanks have been identified and listed for each truck. Figures A19, A20, A21, \& A22 depict such a listing for truck system \#4. A similar listing has been generated for each truck on a truck system basis. During the previous reporting period, the listing for truck system \#3 was shown since it was undergoing a planned maintenance and modification outage during that time. During the current reporting period, the listing for truck system \#4 is being shown since a planned maintenance and modification outage for truck system \#4 was initiated in June. During this outage flammable gas modifications are planned for truck system \#4 as well. These modifications primarily rely on elimination of ignition sources in the in-tank and out-of-tank sampling and support equipment exposed to flammable gas pathways. It is anticipated that because of the extensive modifications planned for this truck system, they will not be completed until well into the next reporting period. The full scope of flammable gas modifications necessary to the truck systems was documented during this reporting period in Corbett [1996].

Previously established weekly meetings involving design engineering, field engineering, operations, and maintenance to review and status the required modifications to each truck system continued during this reporting period and are intended to be an ongoing activity. Normally, the 
truck system currently in a planned outage and/or the next truck system scheduled for an outage are concentrated on during this meeting. Truck system \#4 was the only one to undergo an outage during this reporting period.

As reported previously, specific improvements (reliability and flammable gas) to the remote latching unit mechanism (RLU) design were made, were being tested, and were intended to be deployed during the current reporting period. In actuality, testing and fabrication were completed during this reporting period but the new mechanical RLU will not be installed on truck \#4 (see Figure A18) and put into field service until completion of the truck \#4 maintenance and modification outage, sometime in August 1996. The RLU is used to set and retrieve samplers in the drill string.

\subsubsection{Management of Equipment Problems}

Management of equipment problems continues as reported previously. Logbooks are kept by Characterization Operations and Characterization Field Engineering for each truck system. These are used to document equipment problems experienced in the field and other field-related activities. A sampling problem database created by Characterization Equipment Design is used to collect, sort, analyze, assign responsibility, and document closure for problems related to sampling operations and equipment, as gleaned from the logbook systems identified. The database is available to everyone on the Characterization Project via a computer drive on the local area network. It can be found at network share, IIWHC128\ACTLOG, commonly referred to as "K" drive. During the reporting period an additional 211 "problem" entries were made to this database (see Figures A23 through A29). As can be seen from these figures, not all of these are specific sampling equipment problems demanding engineering attention. Many are smaller "problems" requiring a maintenance response and many are of a personnel or material resource nature. A few involve the language or interpretation of operating procedures. The weekly meeting established between representatives of design engineering, field engineering, operations, and maintenenace during the last reporting period was continued during this period and will be an ongoing activity. The purpose of this meeting is to review the weekly input to the "problem" database and establish problem solution responsibility. Those problems designated as belonging to design engineering are further reviewed within design engineering and are assigned to an individual engineer to resolve. If it's determined that the solution requires an equipment design modification, that is so noted and the required modification is added to the truck system modification database (see item 2.2.2 above).

It was reported previously that the number one cause of sampling equipment downtime has been associated with the grapple hoist system. For the first half of FY96 this problem area had accounted for a full $24 \%$ of equipment unavailability. As can be seen from combing the 211 entries in Figures A23 through A29 this continues to be the number one problem, followed by 
RLU and hydraulic system problems. It should be noted, however, that some entries refer to the same instance of a problem. It's just that they are reported from a different source, i.e., the operations $\log (\mathrm{O})$, engineering $\log (\mathrm{E})$, or the Job control system (J). As reported previously, some modifications have been implemented to address these high profile problem areas. Others, e.g., cable level-wind system, are stilled planned for implementation.

It is well recognized that all equipment field problems are not the result of faulty design. Sometimes the fault can be traced to faulty procedures. Often problems are the result of human error or lack of training or understanding of how the equipment is intended to function. In an effort to improve equipment availability (or incidence of unavailability) as regards operator understanding Characterization Equipment Design initiated (earlier in FY96) a supplemental "training" program for operations and maintenance personnel. Once a week, for four weeks, each of the four shifts is trained in a specific area of sampling equipment operation. During this reporting period three such sessions were conducted which included the topic areas of:

o April 18, 1996 through May 9, 1996 - Modifications to Truck \#3 and Truck \#4.

o May 16, 1996 through June 6, 1996 - Sampling Truck On-board Hydraulic System - basic operation, limits of operations, operational care and maintenance, problem recognition.

- June 13, 1996 through July 11, 1996 - Nitrogen Purge Gas System (N2 Trailer and Sampling Truck) - basic operation, control system, associated hazards of operation, problem recognition, flammable gas modifications

- June 13, 1996 through July 11, 1996 - Exhauster System - flammable gas modifications, new Flammable Gas Detection System.

During the previous reporting period it was reported that a new, unique problem surfaced as a result of mixing and interchanging truck system component equipment in the field in response to certain components being or becoming inoperative and in order to not have to cease sampling operations. The problem was one of "similar" or "like" pieces of support equipment not being truly "interchangeable", and the resultant damage caused by these incompatibilities. It was also reported that short term controls were effected, and that long term solutions plannned included: 1) creating and maintaining truck system design configurations, and 2) modifying existing and new pieces of truck system component equipment to enhance interchangeability. The first long term solution has been initiated but will not be fully implemented until the next reporting period, so discussion of same will be deferred to that time. The second long term solution is well under way as was seen earlier in Section 2.2.1. Cartoons (Figures A14, Al5, A16 \& A17) depicting present truck system configuration have been modified from those previously reported and show progress towards achieving equipment interchangeability. Continued equipment modifications are planned to achieve the future configurations shown in Figures A30, A31, A32, \& A33. [Note: Truck \#1 differs from $\# 2, \# 3$, and $\# 4$ since it is only capable of push-mode operation, whereas, the 
others are capable of rotary-mode as well]. No new, unique problems surfaced during this reporting period.

\subsubsection{Equipment Problem Analysis/Corrective Actions}

As reported in the past, the immediate response to an equipment problem in the field that shuts down operations is normally one of repair-in-place or replace with a spare component to facilitate resumption of operations whenever possible. After the fact, the problem or failure is analyzed as to cause and whether corrective actions in the form of equipment modifications are warranted. In some instances the root cause of the problem or failure is not readily apparent and an analysis is required. During this reporting period no new equipment problems or failures were encountered. Consequently no analyses or corrective actions were required.

During this period, as well as the previous one, core sampling was limited to push-mode only because of flammable gas issues with rotary-mode sampling. It was previously reported that in an effort to permit higher downforces when in push-mode, tank riser sleeves were designed, fabricated, and deployed to act as strongbacks for the drill string which is inserted through them. And, that an analysis report was commissioned to support operation in both push- and rotarymode operation with riser sleeves of various lengths. This analysis (Ziada [1996]) was completed and formally issued during this reporting period. The analysis computes and reports the permissable downforces to be used during both push-mode and rotary-mode, at various drill string rpm.

\subsubsection{Availability/Reliability Evaluations}

As reported previously, the working definitions for availability and reliability of sampling equipment have been established in Janicek (1995). As defined, the availability of CSSs is tracked daily. Concurrence in equipment status is established between Characterization Equipment Engineering and Characterization Operations. Equipment availability, as shown in Figures A34 \& A35, was $69 \%$ for this reporting period and $66 \%$ overall average for the first three quarters of FY96. Contrast this with $57 \%$ and $72 \%$, respectively, for the first and second quarters of FY96 and overall average $64.5 \%$ for first half of FY 96 .

During the current reporting period the schedule of tanks to be sampled was again revised to accommodate push-mode sampling since rotary-mode gas flammability issues were still undergoing resolution. Meanwhile, modifications addressing flammable gas issues were initiated on truck system \#4. It is anticipated that all modifications can be implemented to enable truck system \#4 to commence rotary-mode field operations sometime during the next reporting period. [NOTE: The time that any given truck system is down for a planned maintenance and modification outage is "charged" as unavailable time for purposes of calculation]. The FY96 goal of attaining an average $65 \%$ availability was achieved at the very end of this reporting period. 
WHC-SD-WM-RPT-251

Rev. 0

14

\subsection{CURRENT ISSUES}

It is imperative that rotary-mode sampling operation is achieved soon. The ability to sample in push-mode alone is fast becoming limited as higher and higher push-mode down forces are being required to obtain full sample cores in the remaining waste tanks. During this reporting period a number of cores had to be terminated short of their goal because of this.

Approval of the "Safety Assessment of the Rotary Mode Core Sampling In Flammable Gas Single Shell Tanks, Hanford Site, Richland, Washington" is expected by the end of July 1996. The second and third tier reviews have been completed and completion and final approval by DOE will allow sampling of flammable gas tanks.

Qualification for the Rotary Mode Core Drilling in Flammable Gas Tanks is pending the completion of the DOE Operational Readiness Evaluation for operating the RMCS System in flammable gas environment is scheduled to complete in September 1996, this will permit starting sampling in September 1996.

\subsection{PLANNED ACTIVITIES FOR NEXT REPORTING PERIOD}

Complete ATP/OTP for RMCST \#4 which includes incorporation of the flammable gas modifications noted in WHC-SD-WM-DRR-053, "Design Review Report for RMCST Modifications for Flammable Gas Tanks, Final Design". It is anticipated that the completion of ATP/OTP will be at the end of August 1996

Equipment availability/reliability improvements during this reporting period have mainly focused on hardware. And, in particular, on modifications to support high profile equipment problem areas and flammable gas upgrades to enable returning to rotary-mode operation. This emphasis will continue for the next reporting period. It is anticipated that truck system \#4 modifications will be completed in the next quarter and that it be returned to rotary-mode service. As soon as this can be accomplished truck system $\# 3$ will be brought in for flammable gas (rotary-mode operation) upgrades.

\subsection{REFERENCES}

Blanchard, R.J., 1995, "Improving Sample Recovery, Engineering Task Plan," WHC-SD-WMETP-159, REV. 1, Westinghouse Hanford Company, Richland, Washington.

Janicek, G.P., 1995, “Sampling Equipment Availability/Reliability Improvement, Engineering 
Task Plan “, WHC-SD-WM-ETP-171, REV. 0, Westinghouse Hanford Company, Richland, Washington.

Witwer, K.S., 1996, "Test Plan for Core Drilling Ignitability Testing", WHC-SD-WM-TP-411, REV. 1, Westinghouse Hanford Company, Richland, Washington.

Witwer, K.S., 1996, “Core Drilling Ignitability Testing”, WHC-SD-WM-TRP-257, REV. 0, Westinghouse Hanford Company, Richland, Washington.

Schofield, J.S., 1996, "Sample Recovery Measurement Parameters", Internal Memo, 75210-01695-4, Revision 4.

Ziada, H.H., 1996, "Buckling and Dynamic Analysis of Drill Strings for Core Sampling", WHCSD-WM-ANAL-047, Revision 0, Westinghouse Hanford Company, Richland, Washington.

Corbett, J.E., 1996, "Final Design Review Report for RMCST Modifications for Flammable Gas Tanks", WHC-SD-WM-DRR-053, Revision 0, Westinghouse Hanford Company, Richland, Washington.

Janicek, G,P., 1996, "Characterization Sampling Equipment Status Report - January Through March 1996", WHC-SD-WM-RPT-227, Revision 0, Westinghouse Hanford Company, Richland, Washington. 


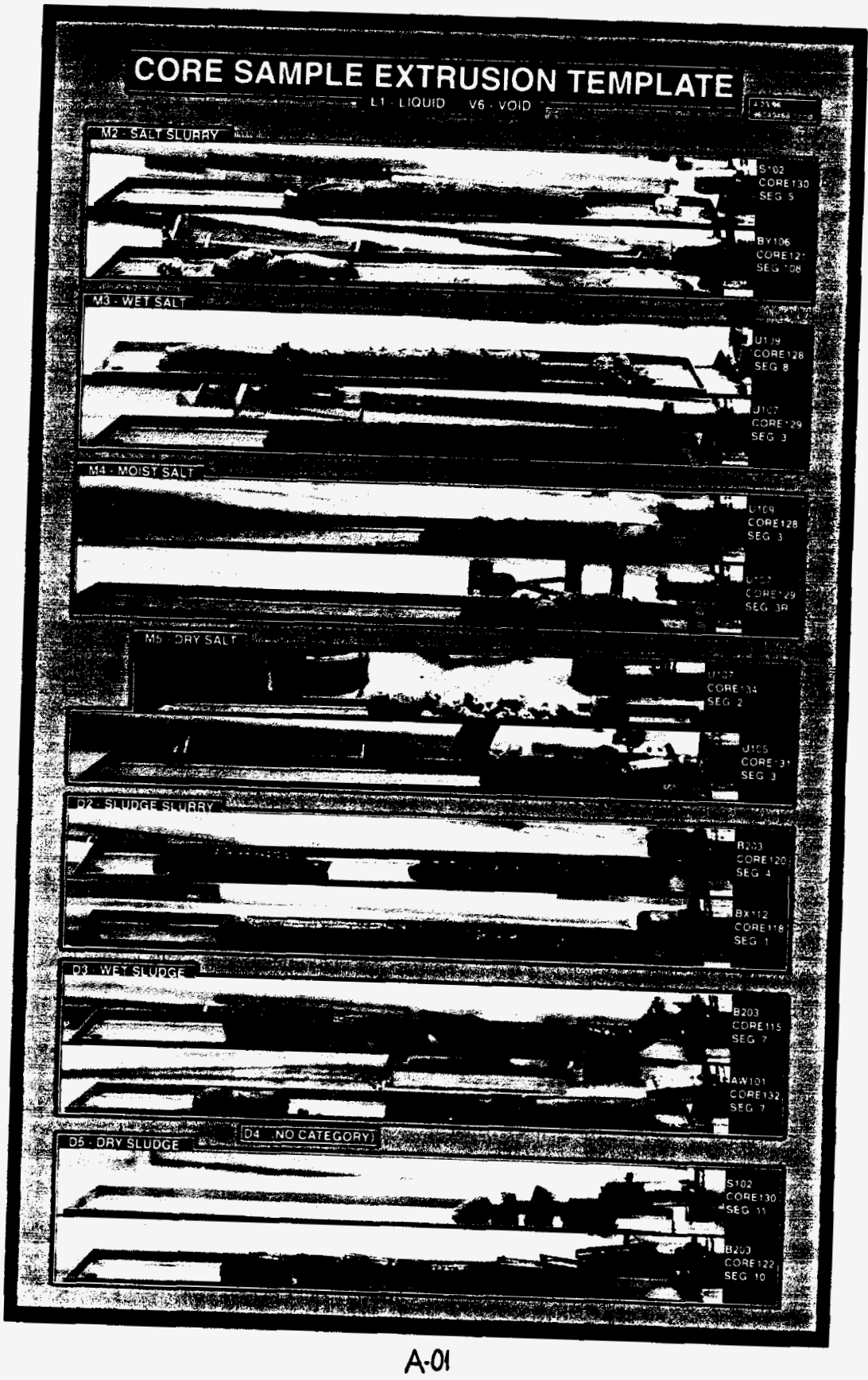




\section{AN-105 PMCS CORE PROFILE}

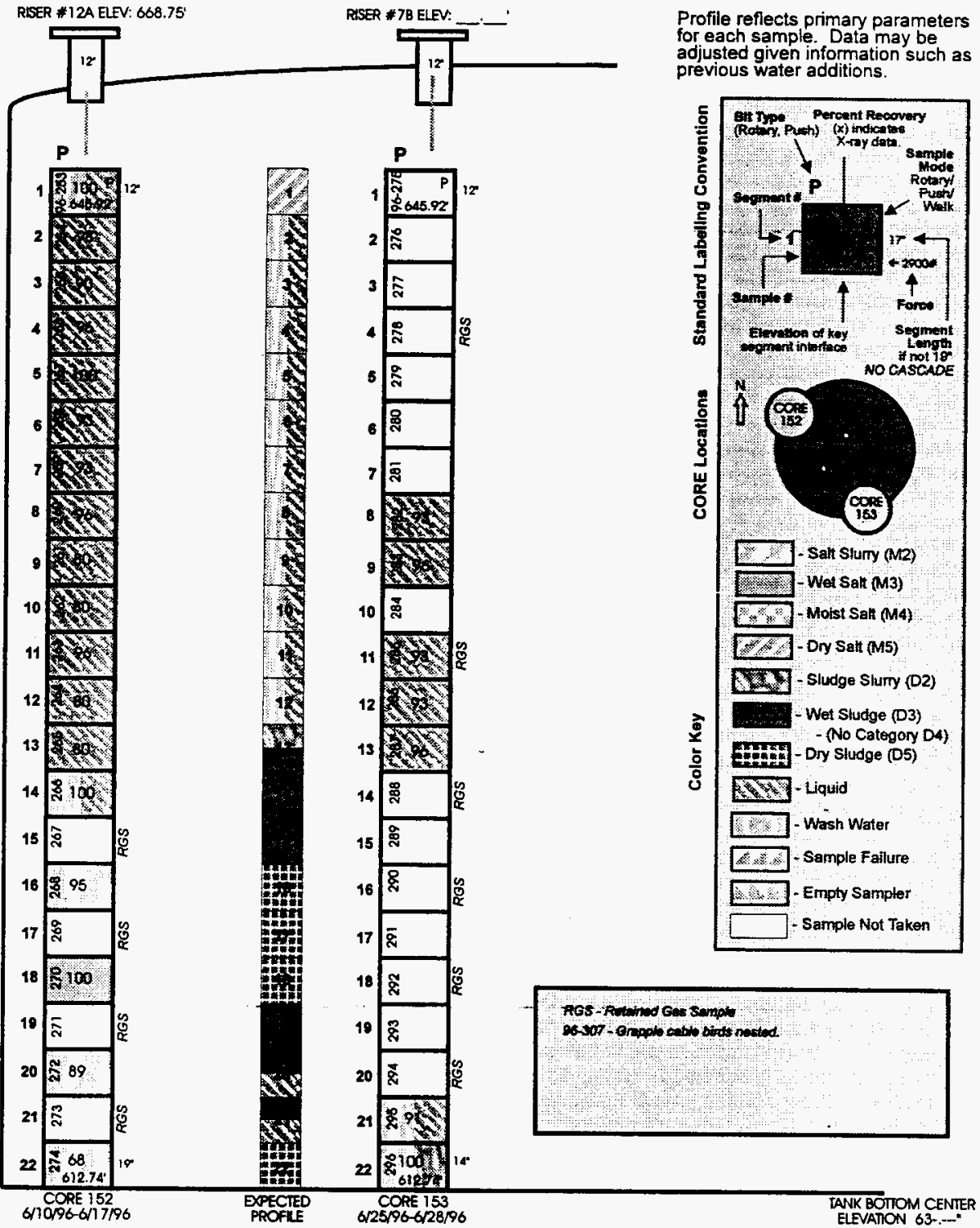




\section{AW-101 PMCS CORE PROFILE}

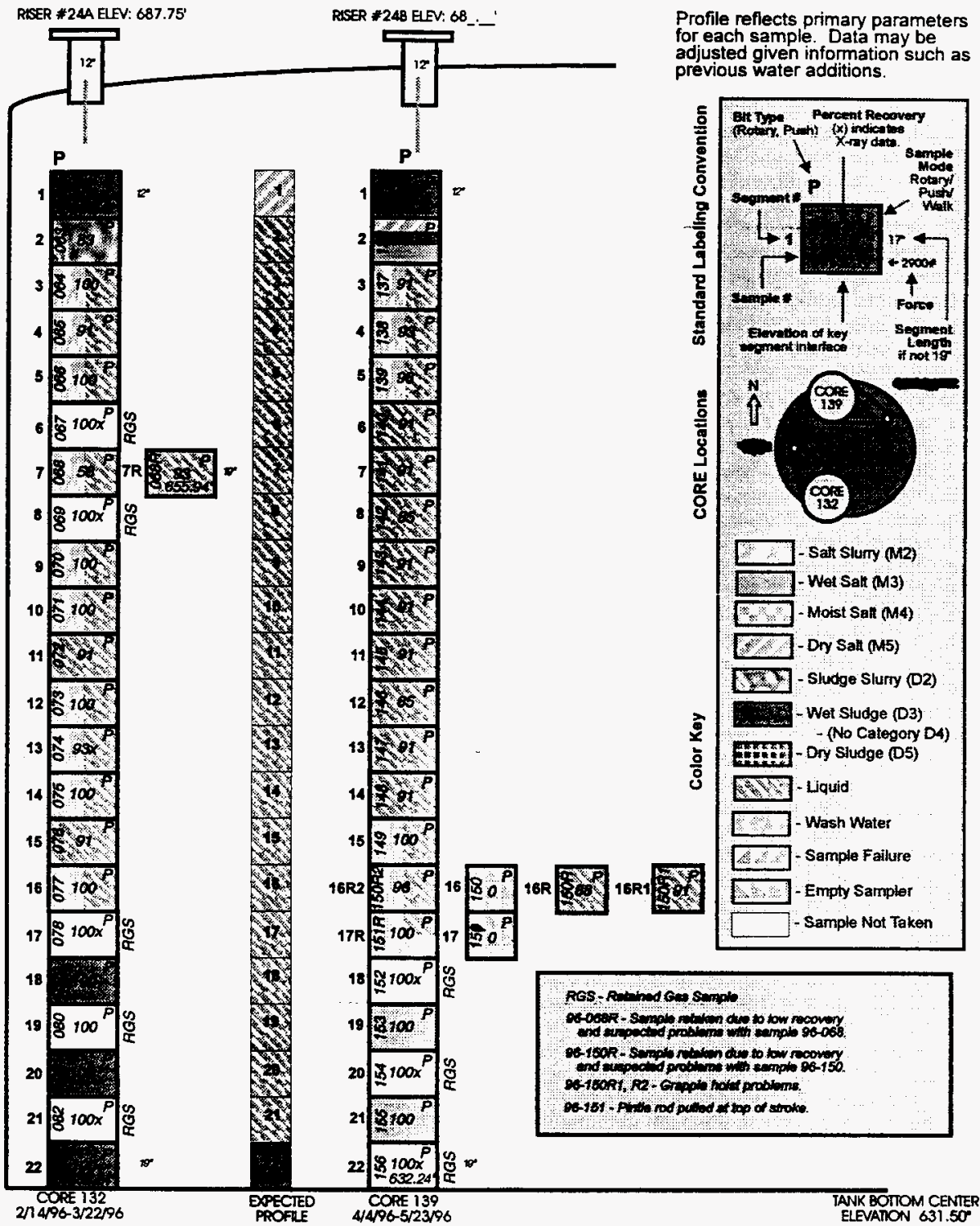



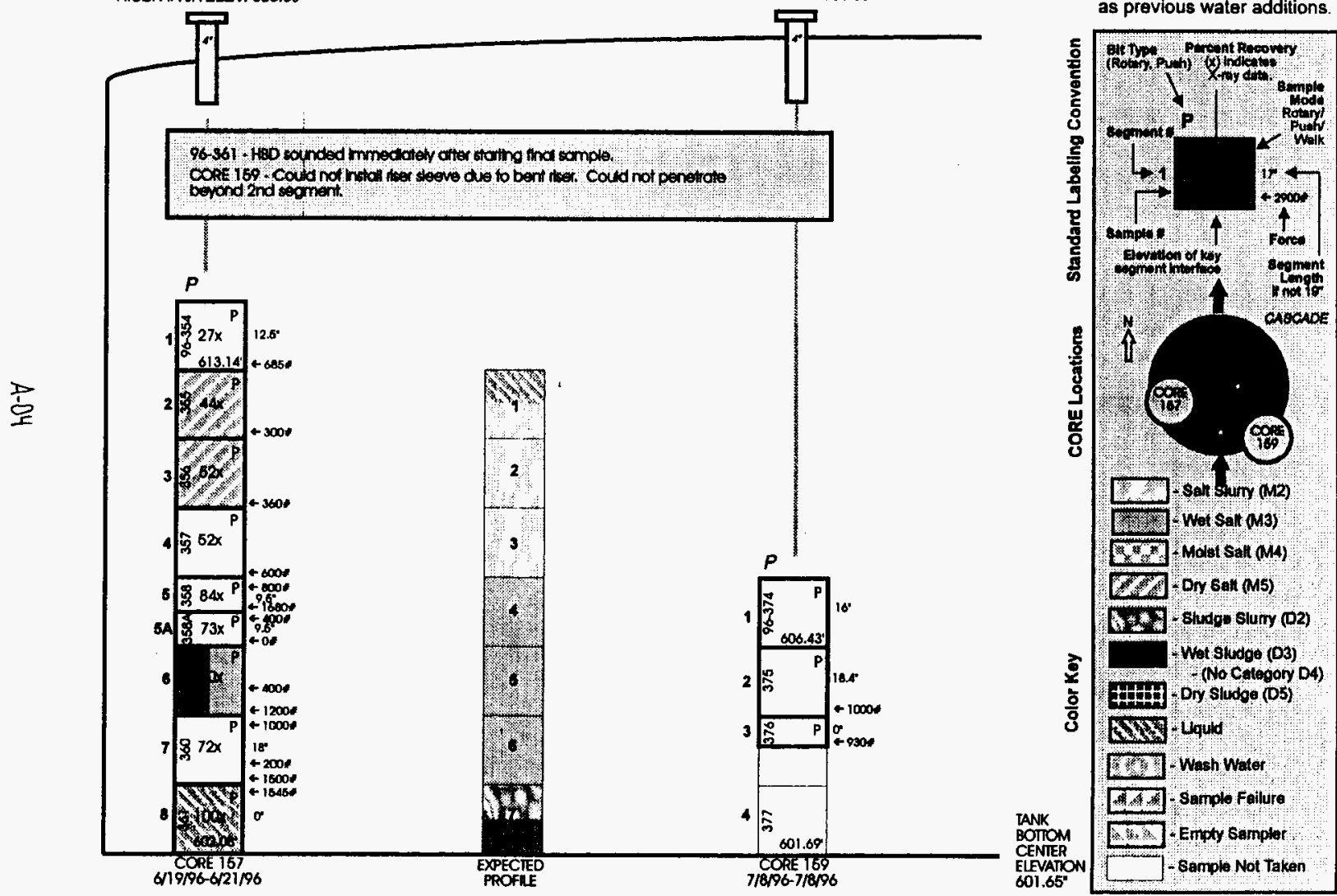


\section{BY-107 RMC8 CORE PROFILE}

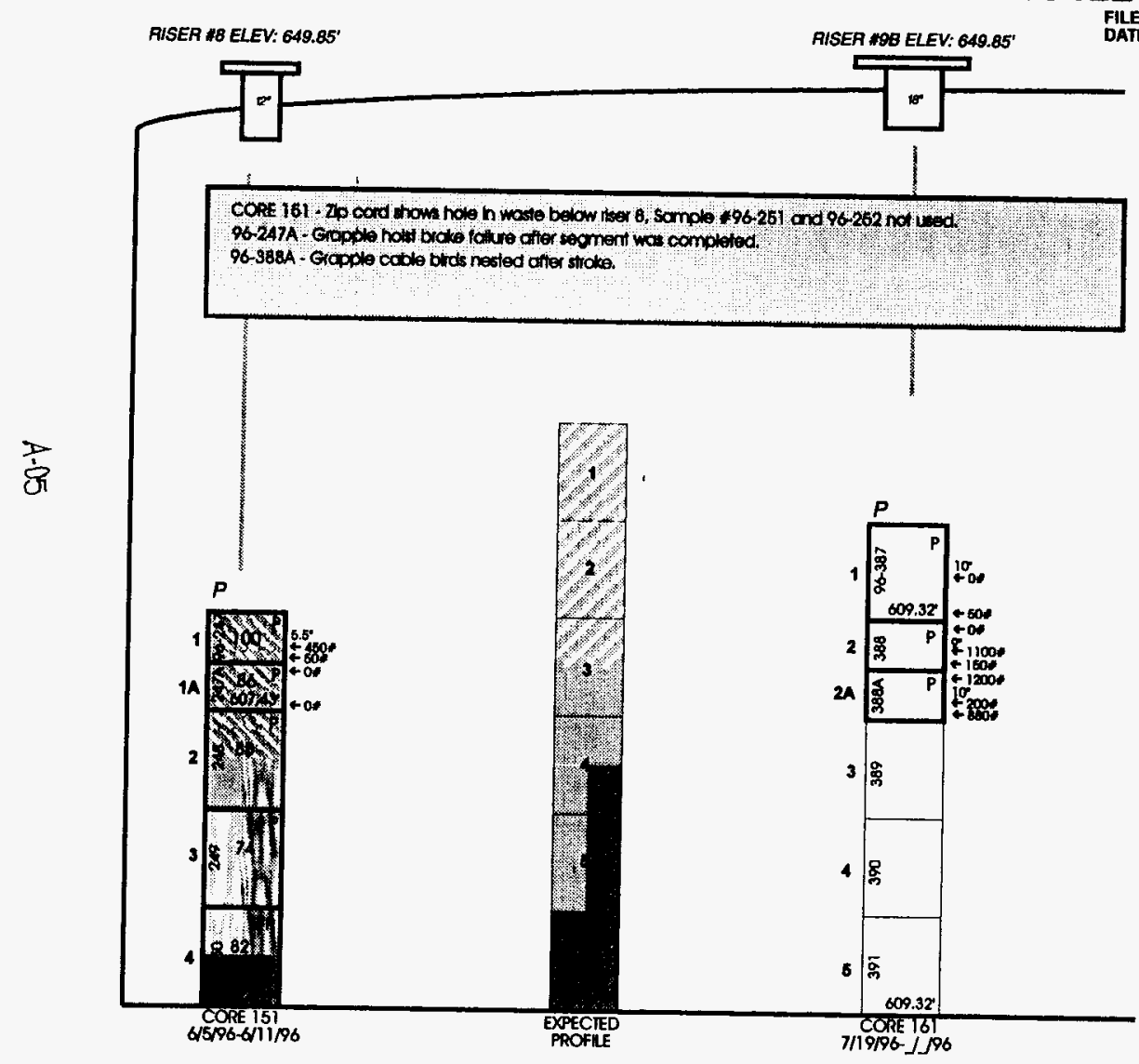

FILE: BY107.CRD parameters for each sample DATE. $07 / 24 / 96$ given information such as previous water additions.

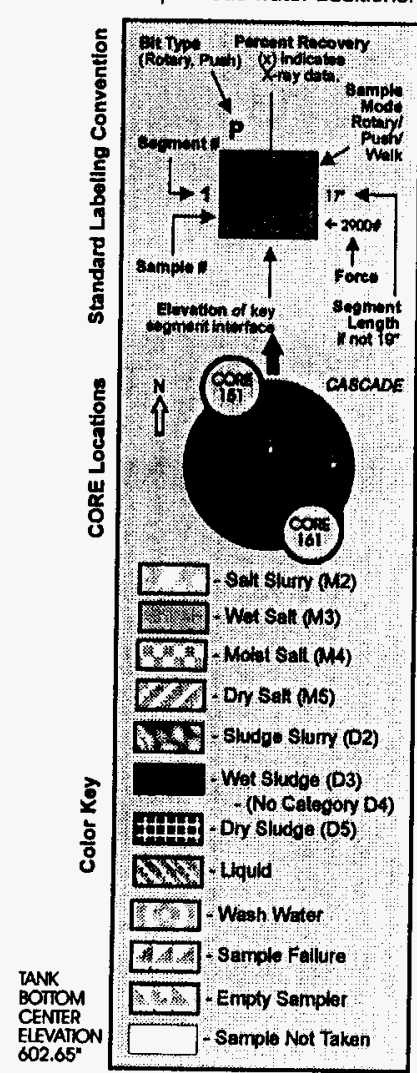




\section{8-101 RMCS CORE PROFILE}

FILE: S101.CRD

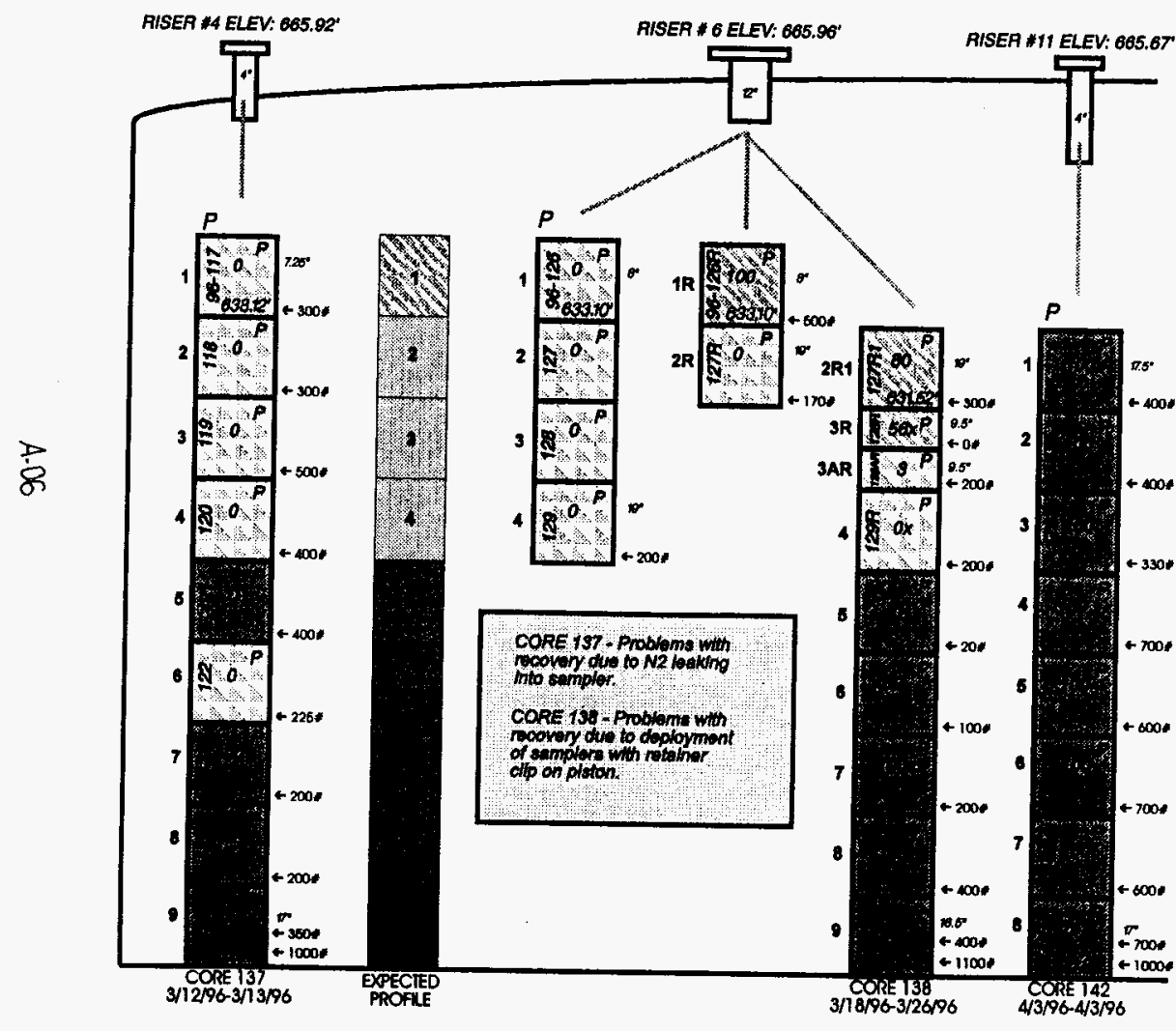

Profile reflects primary

parameters for each sample.

Data may be adjusted

given information such

as previous water additions.

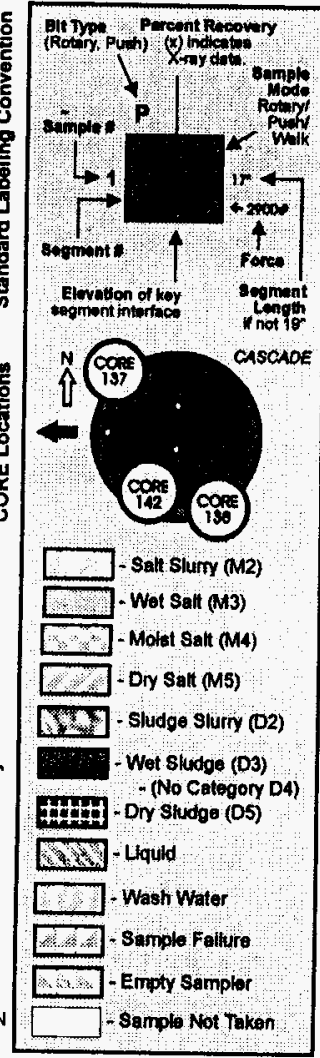




\section{8-109 RMCS CORE PROFILE}

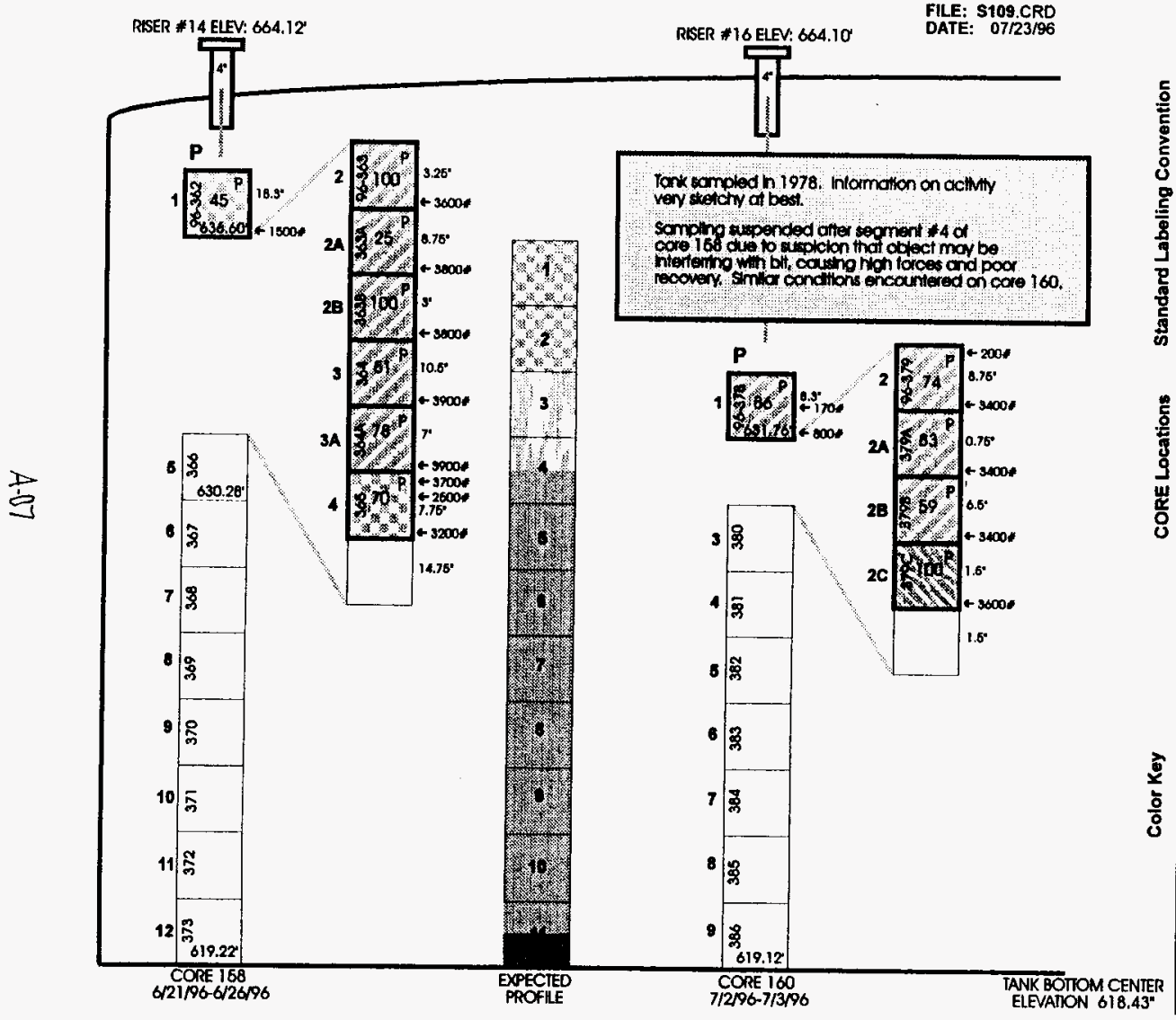

Profile reflects primary

parameters for each sample.

Data may be adjusted

given information such

as previous water additions.

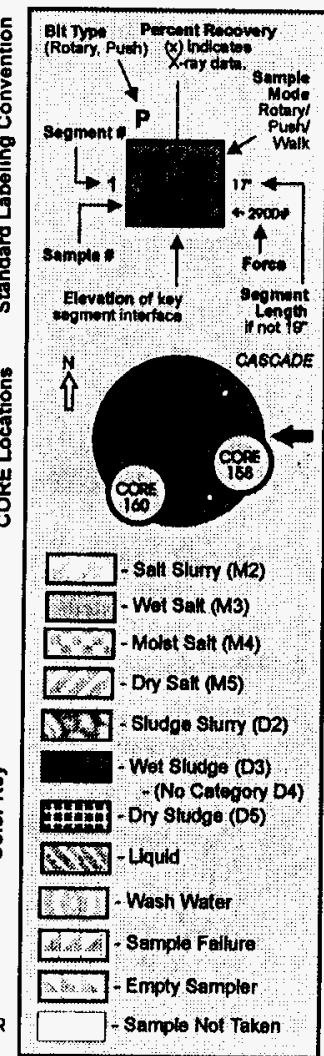




\section{8-111 RMCS CORE PROFILE}

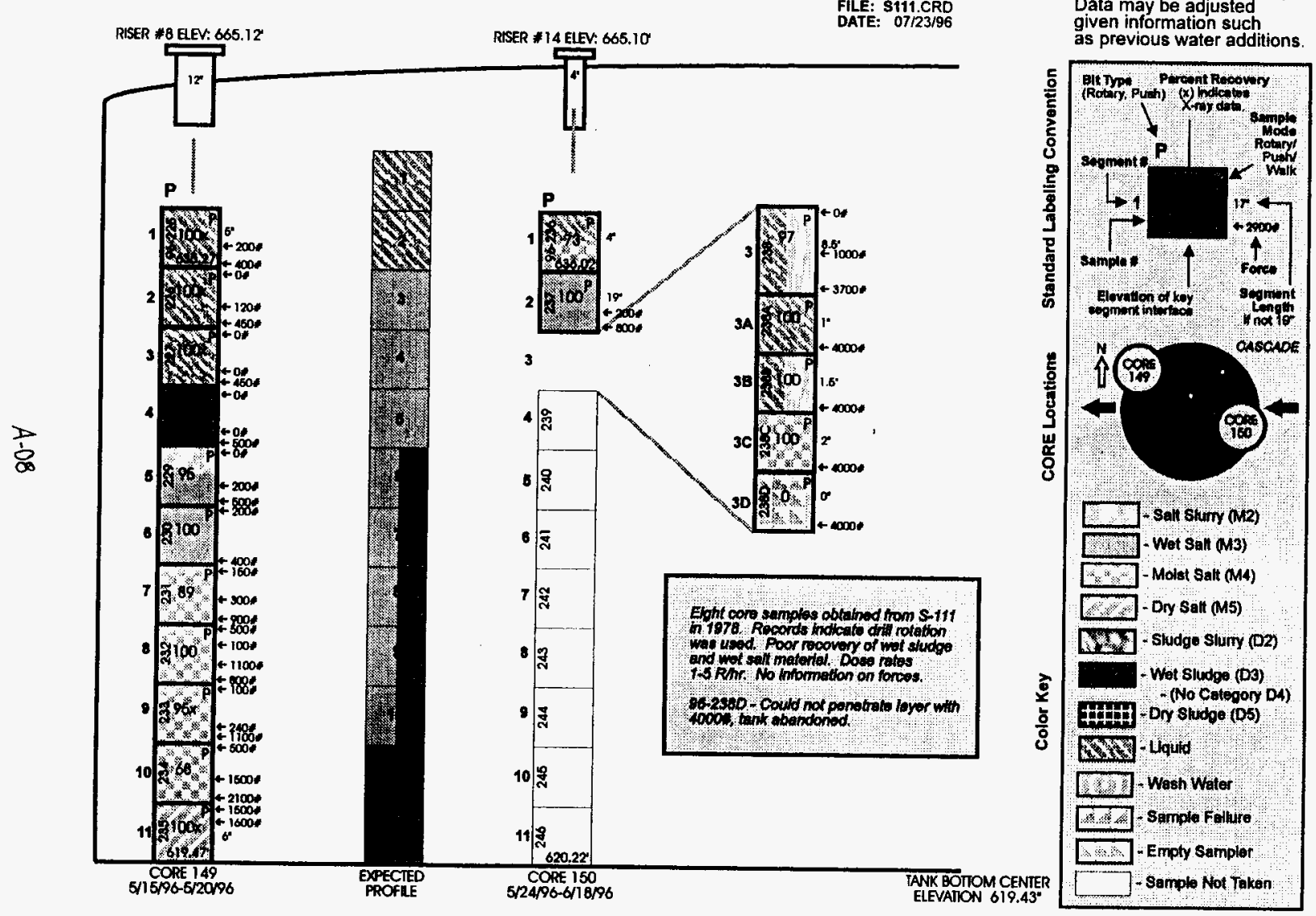

Profile reflects primary parameters for each sample. given information such as previous water additions. 


\section{U-102 RMC8 CORE PROFILE}

FILE: U102.CRD

DATE: 05/17/96

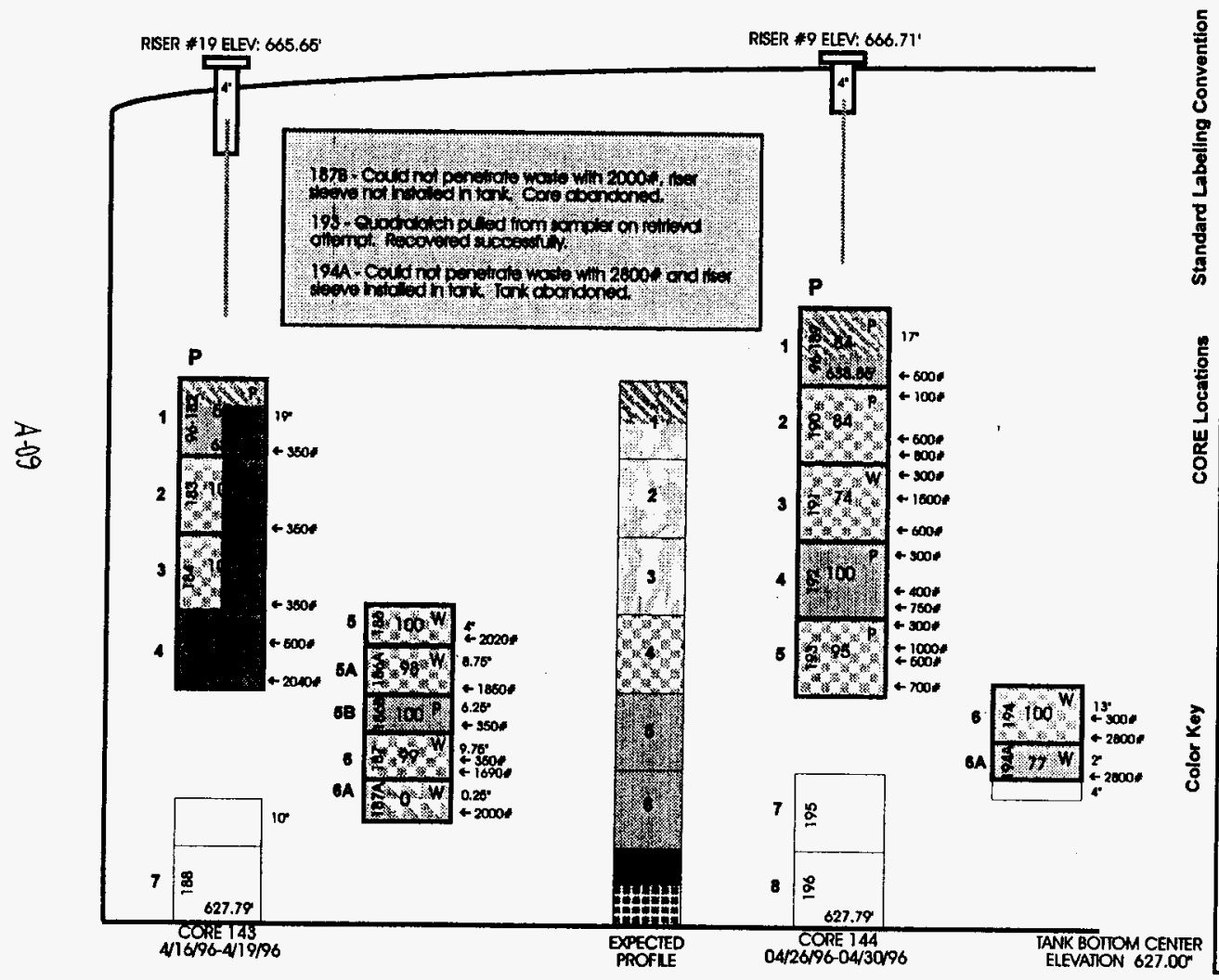

Profile reflects primary

parameters for each sample.

Data may be adjusted

given information such

as previous water additions.

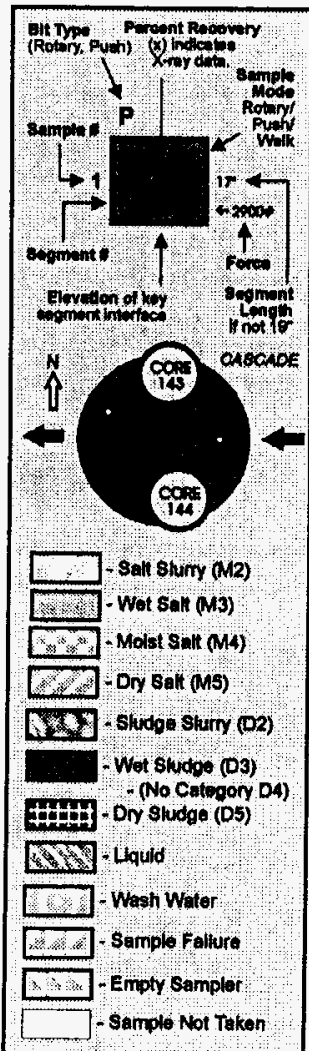




\section{U-106 RMC8 CORE PROFILE}

FILE: U106.CRD

DATE: 05/23/96

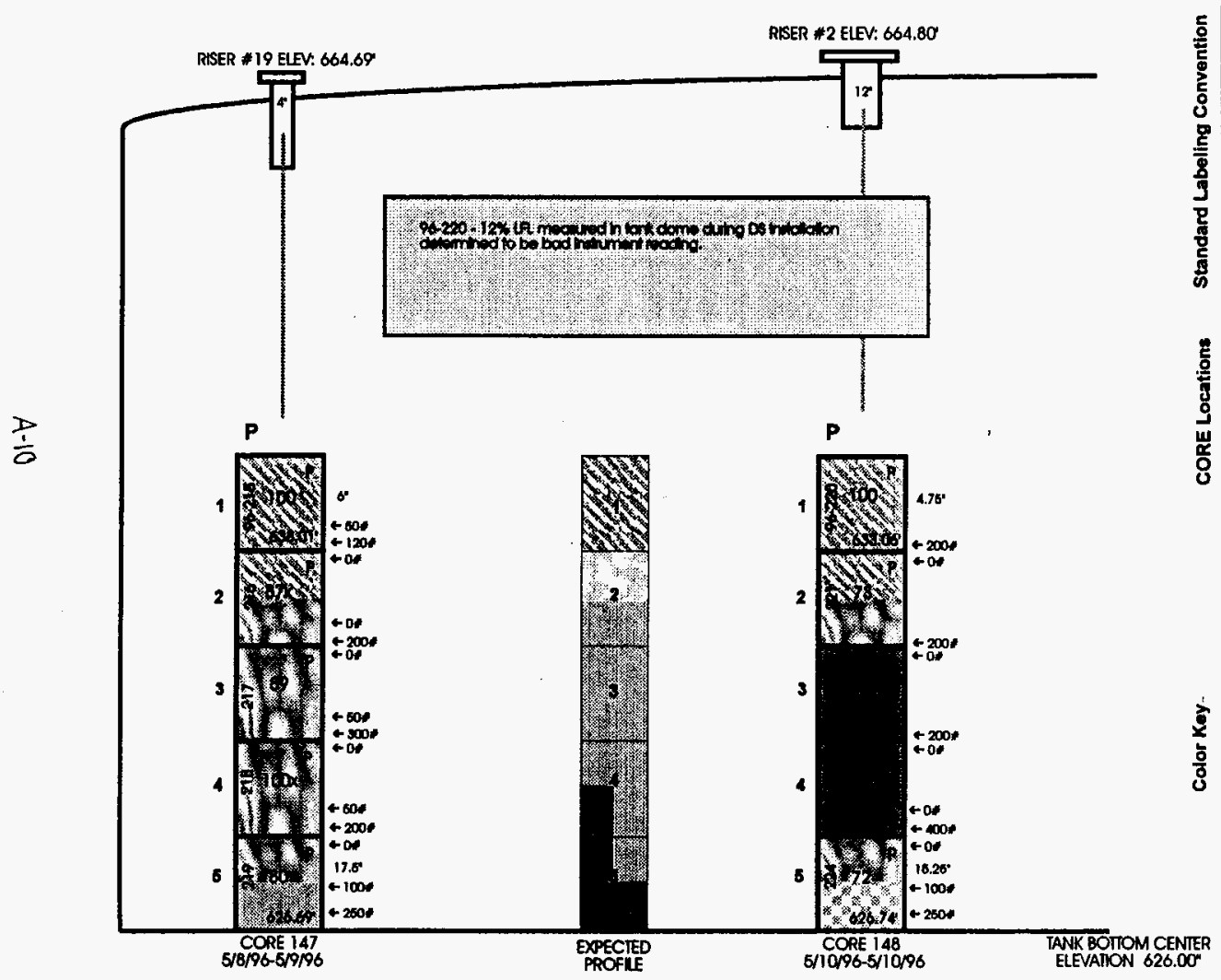

Profile reflects primary parameters for each sample. paramelers lor each given information such given information such
as previous water additions.

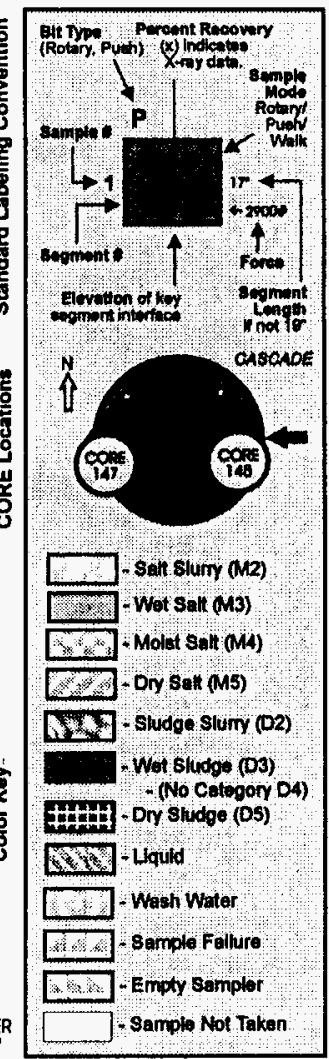



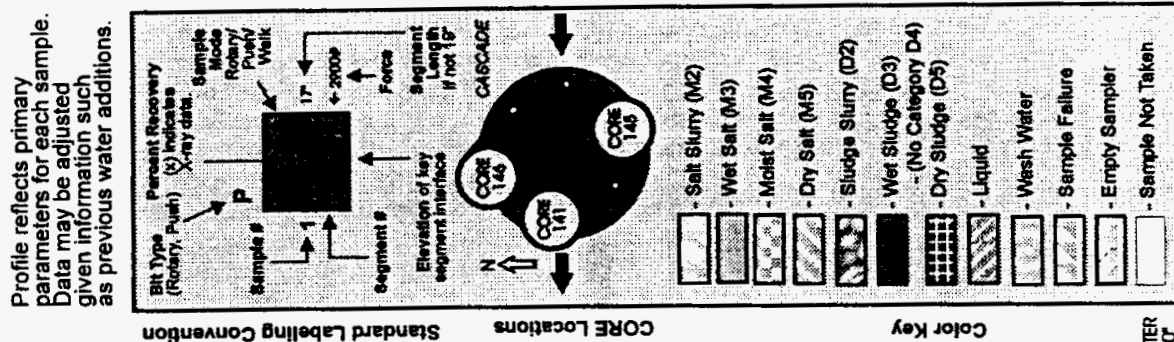

Aey tojos
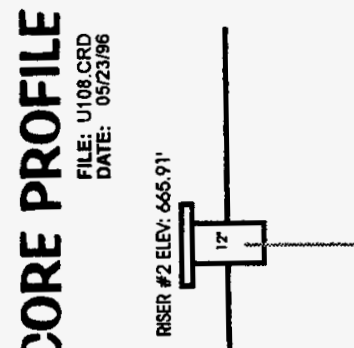

a.

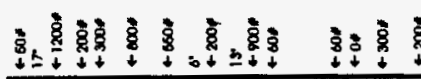

$\frac{1}{0}$

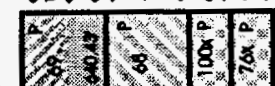

.
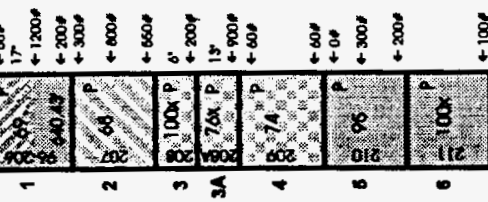

$\frac{8}{+}$

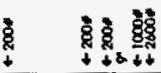

跑

흐잉

诘 풀

$\frac{\infty}{2}$

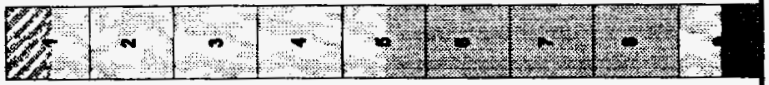

$\infty$

0

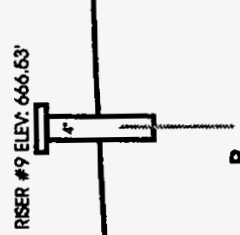

a.
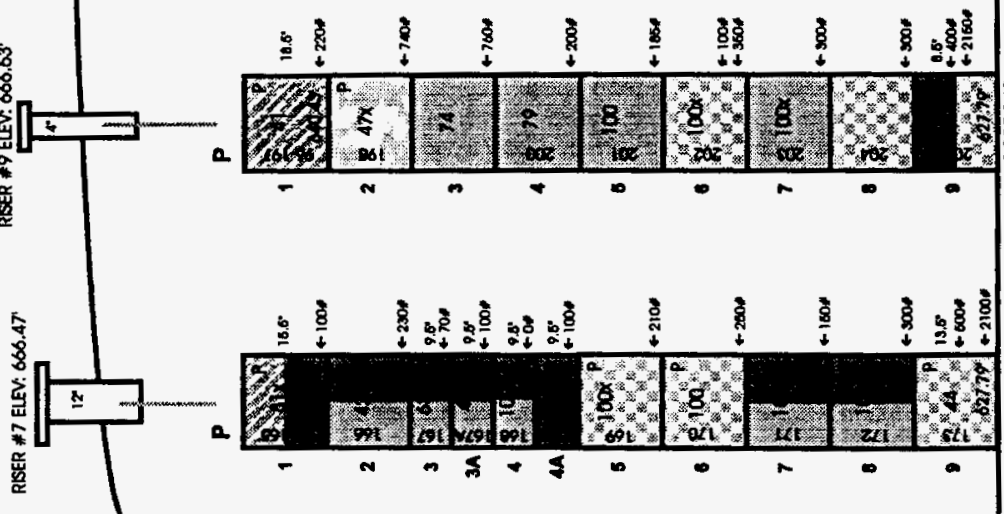
䇏 


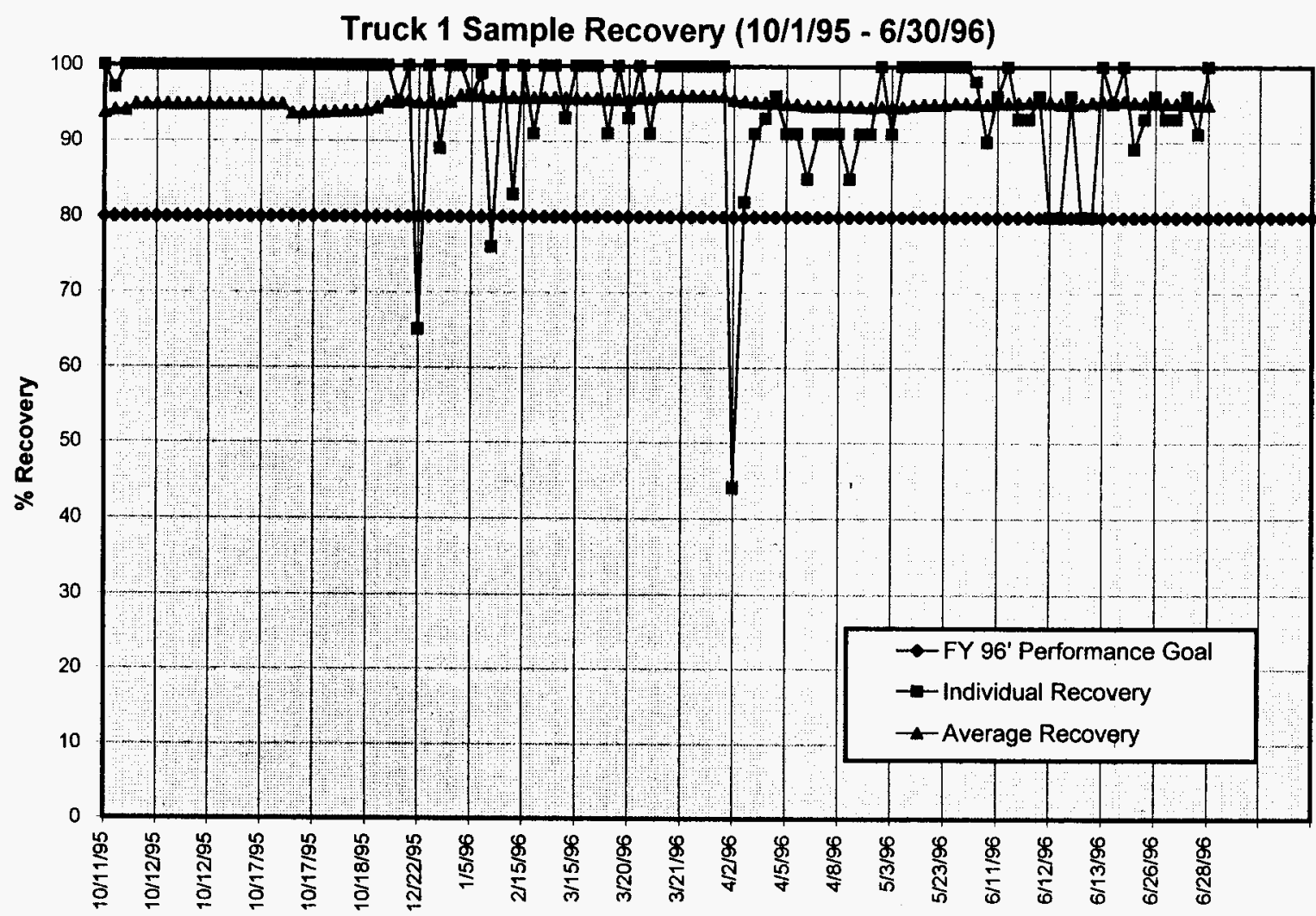




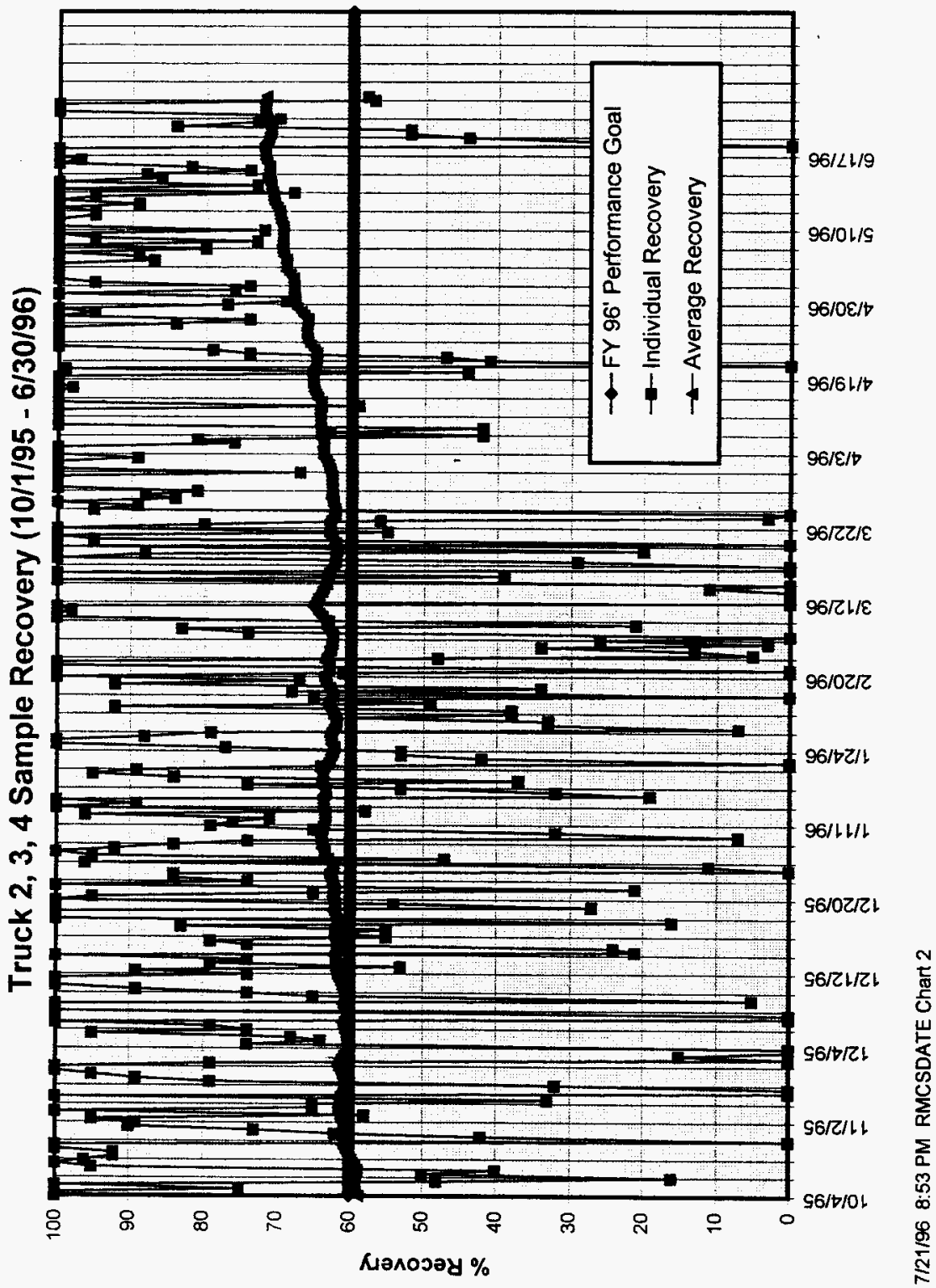


HONDA GEN. 6500VA

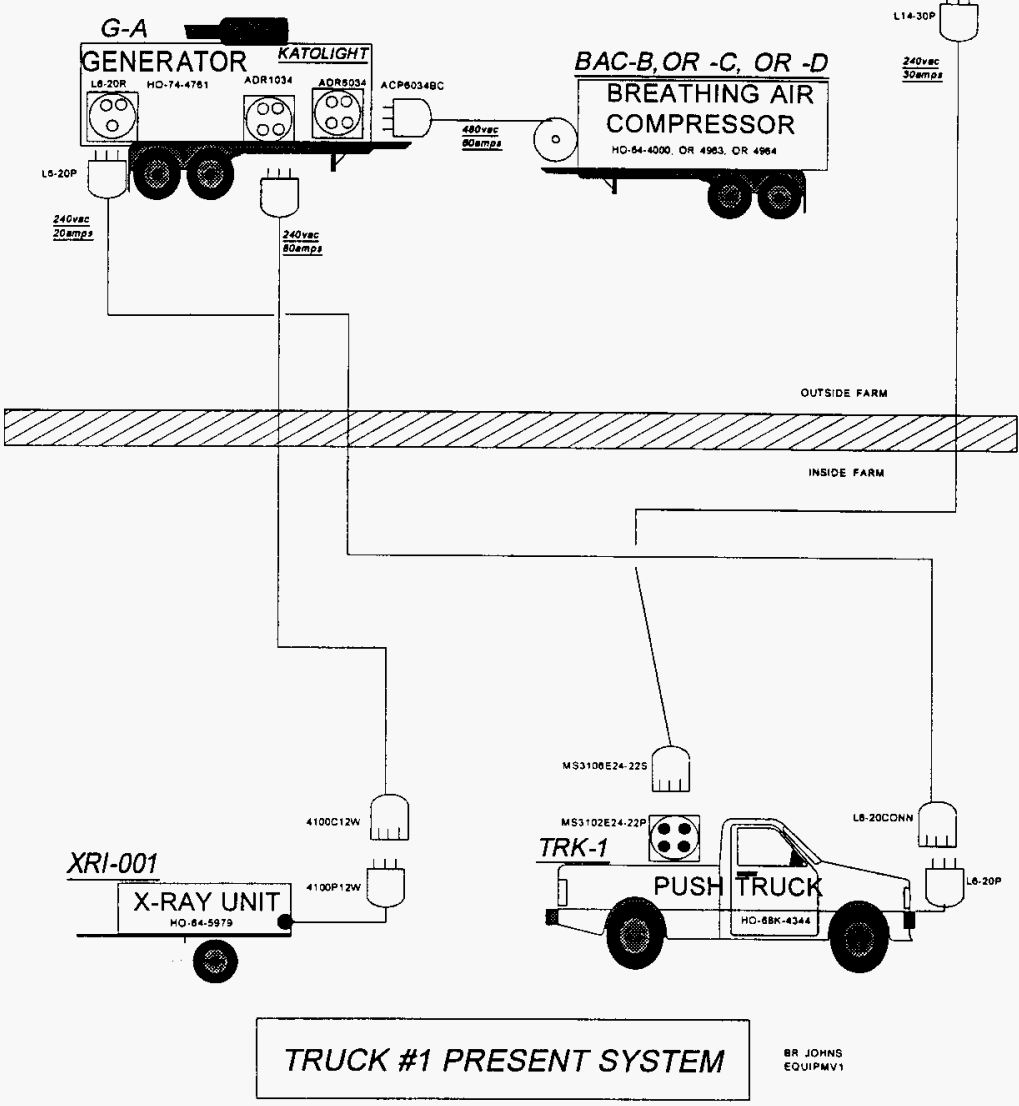




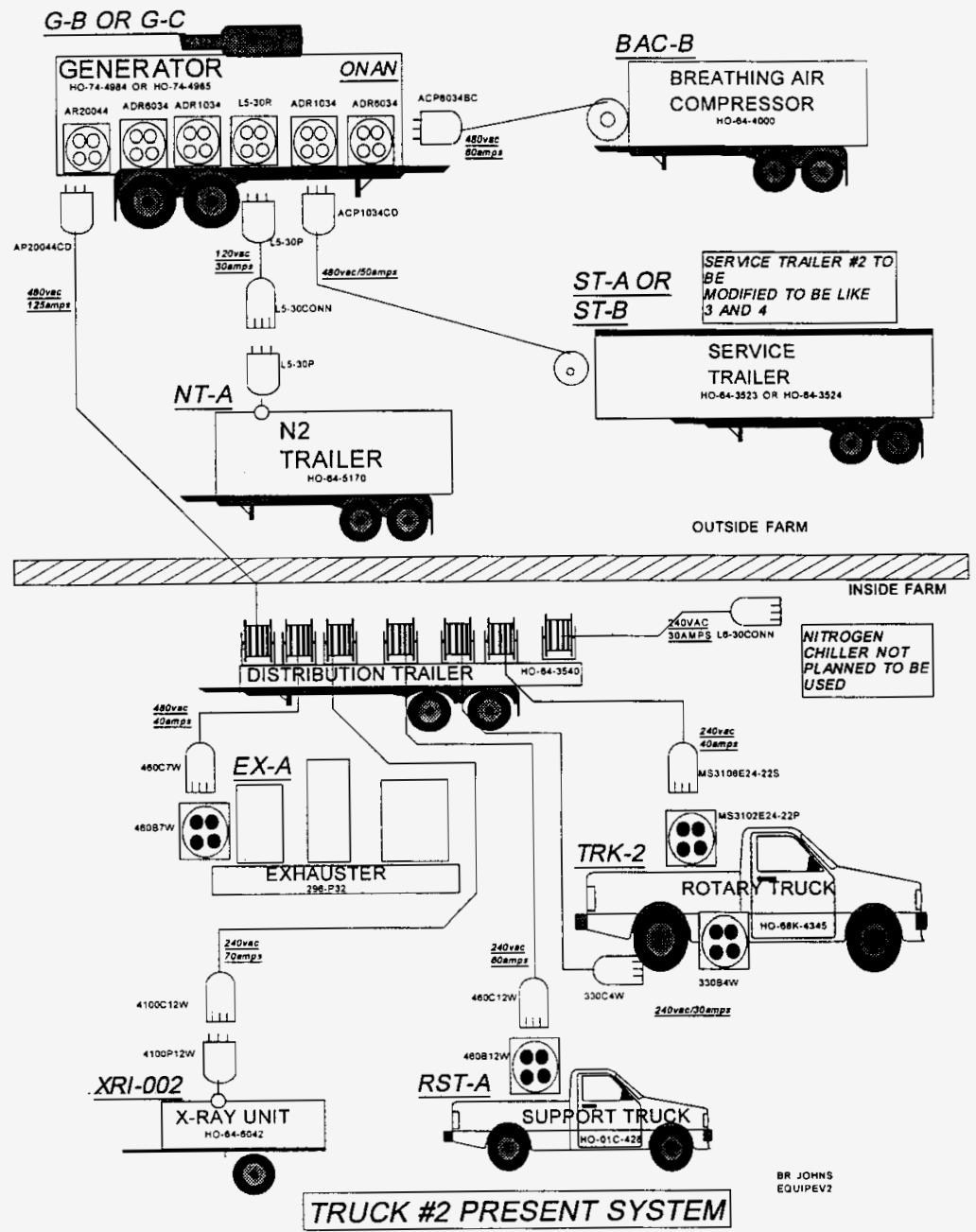




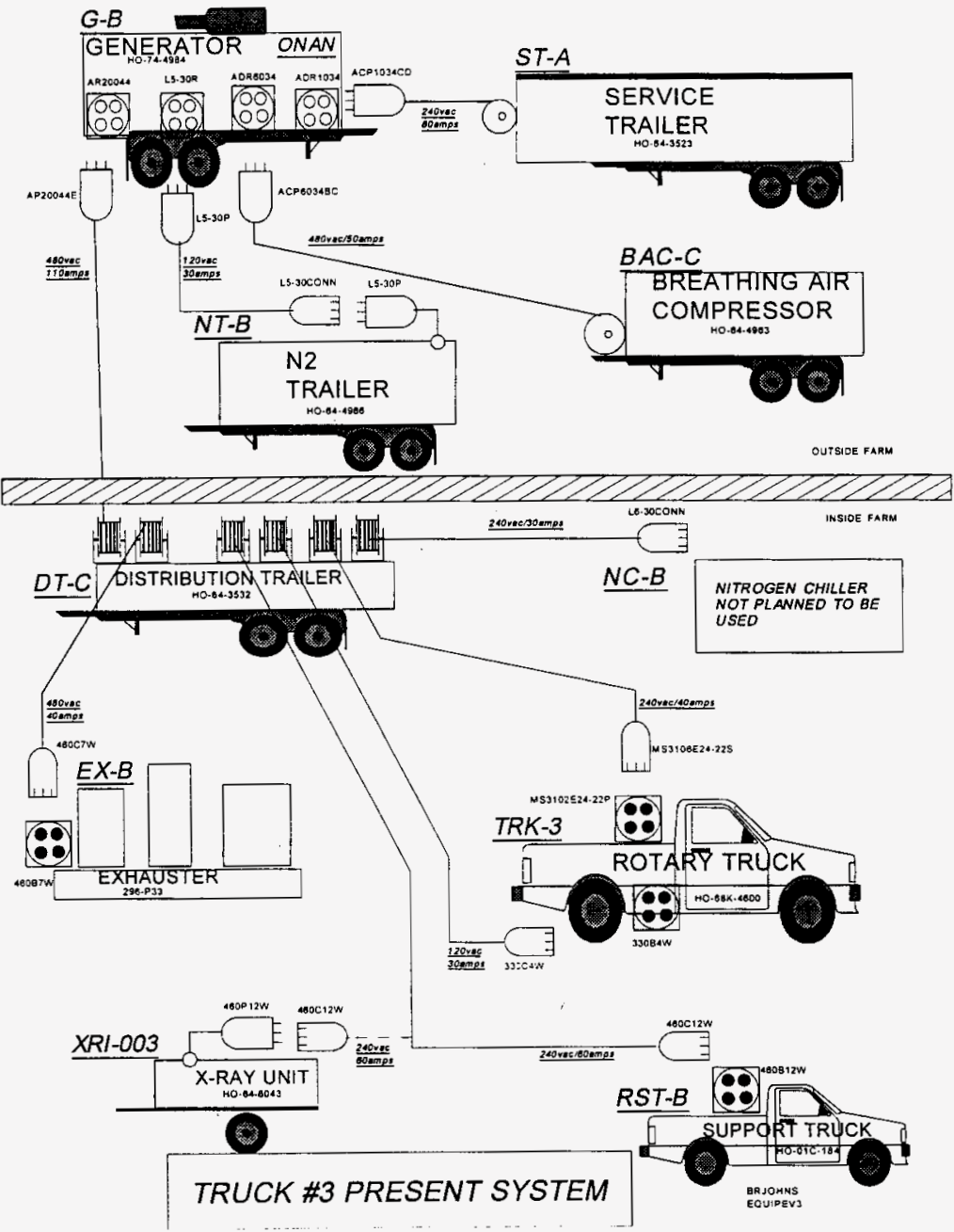




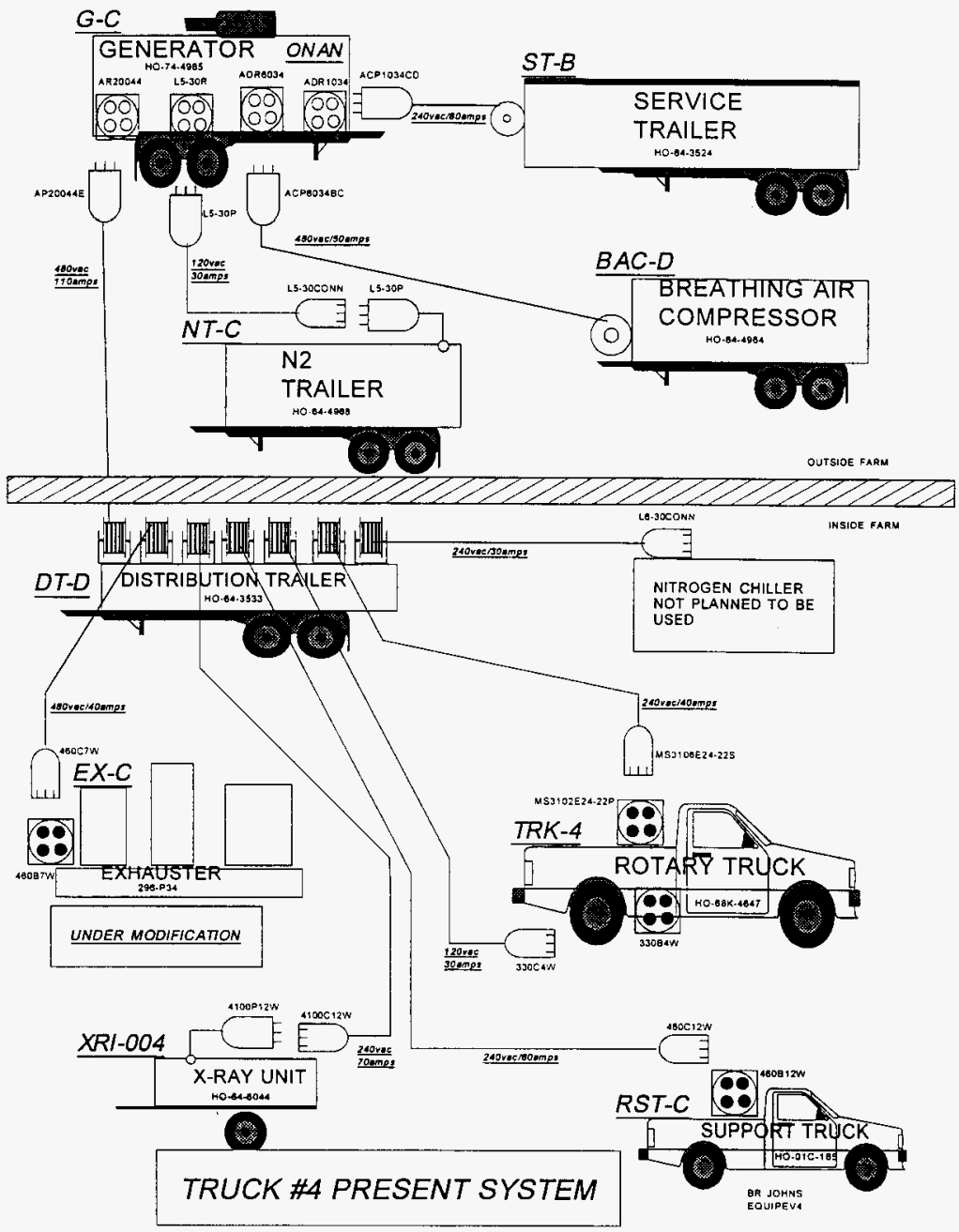




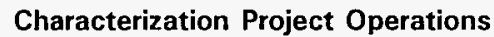

\section{RMCS Reliability Modifications}

RMCS Truck \#

\begin{tabular}{|c|c|c|c|c|}
\hline Description of Modification & 1 & 2 & 3 & 4 \\
\hline 1. Replace purge gas pressure regulator & $\mathbf{n} / \mathbf{a}$ & next & Comp. & Comp. \\
\hline 2. Modify grapple hoist drum & $\mathbf{n} / \mathbf{a}$ & ECN & Comp. & Comp. \\
\hline 3. Modify grapple load cell & $n / \mathbf{a}$ & ECN & Comp. & Comp. \\
\hline 4. Modify mechanical counters & ECN & ECN & Comp. & Comp. \\
\hline $\begin{array}{l}\text { 5. Modify remote latch unit (RLU) hoist drum spool to } \\
\text { incorporate a cable level-wind system }\end{array}$ & ECN & ECN & *10/96 & *8/96 \\
\hline $\begin{array}{l}\text { 6. Replace current electrical RLU with mechanical } \\
\text { RLU }\end{array}$ & ECN & ECN & *10/96 & *8/96 \\
\hline 7. Provide new pendant control & next & next & $10 / 96$ & next \\
\hline 8. Replace pressure transducers & next & next & $10 / 96$ & Comp. \\
\hline 9. Install purge gas filter & $\mathbf{n} / \mathbf{a}$ & next & Comp. & Comp. \\
\hline 10. Provide bellows on shielded receiver & ECN & ECN & ECN & ECN \\
\hline 11. Economy crane replacement & ECN & ECN & ECN & ECN \\
\hline 12. Replace shielded receiver lifting rams & next & Comp. & Comp. & Comp. \\
\hline 13. Modify platform rotation hydraulics & $\mathbf{n} / \mathbf{a}$ & next & next & $8 / 96$ \\
\hline 14. Remove $\mathrm{O}_{2}$ monitor & $\mathbf{n} / \mathbf{a}$ & ECN & Comp. & Comp. \\
\hline
\end{tabular}

* Scheduled with flammable gas modifications.

Next = ECN is complete, ready for next scheduled outage.

$E C N=$ need an ECN or ECN is in signature stage. 


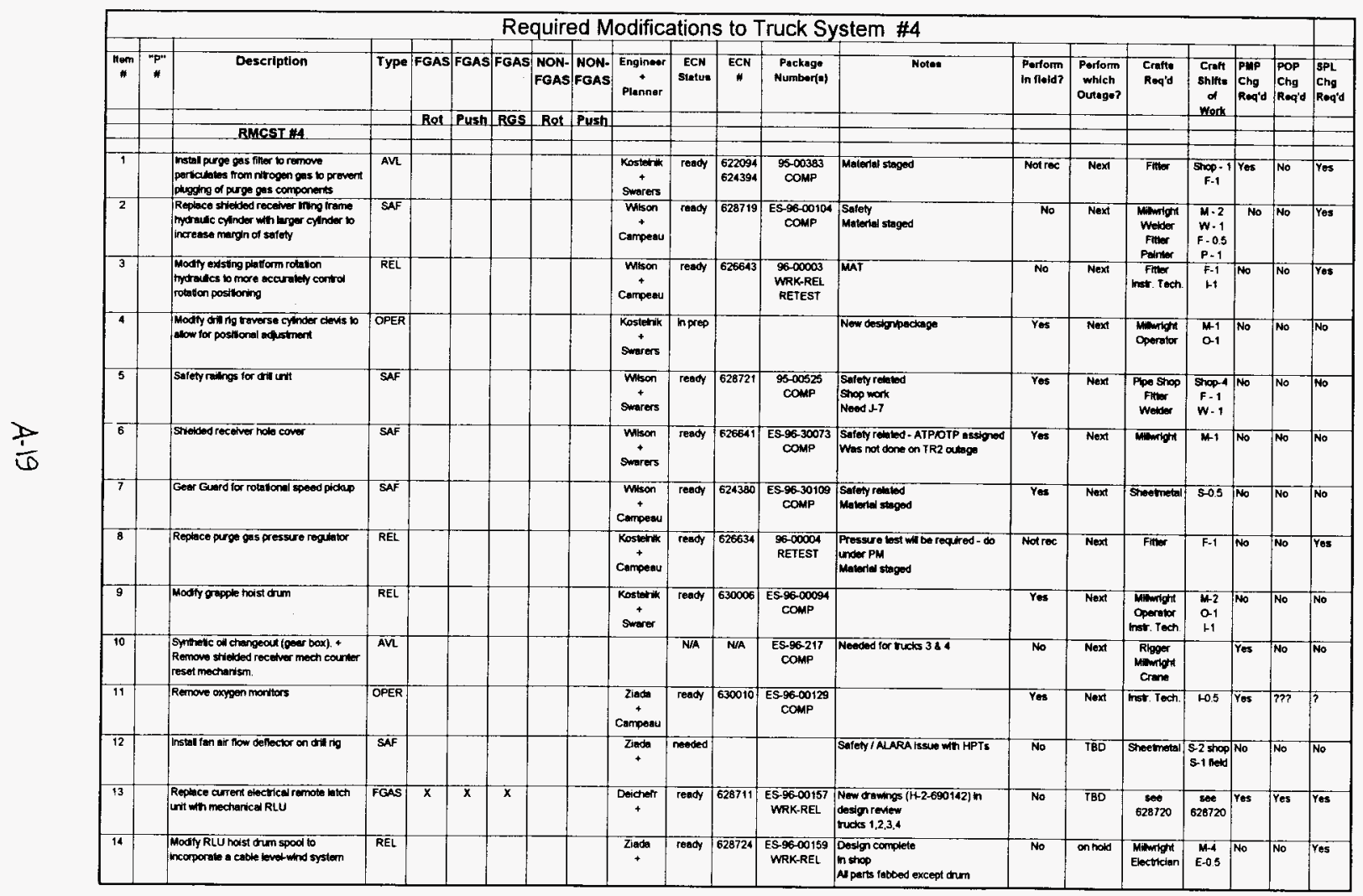




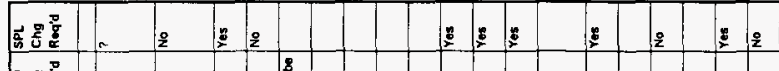

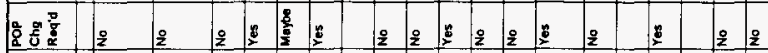

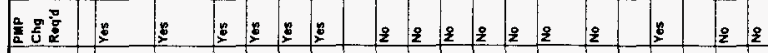

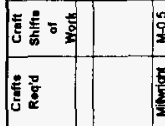

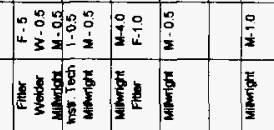

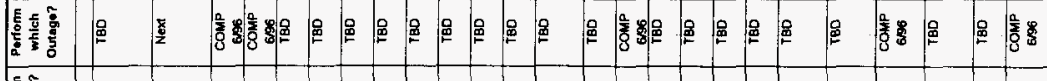

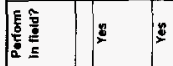

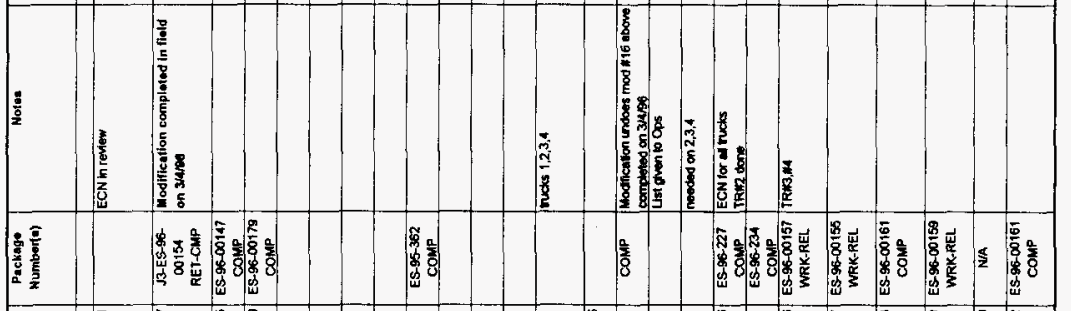

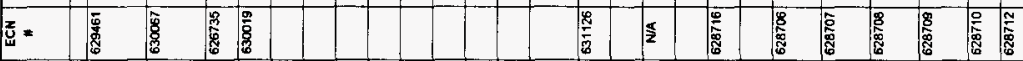

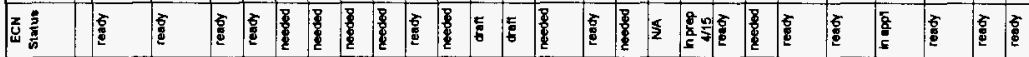
熟, 這 .

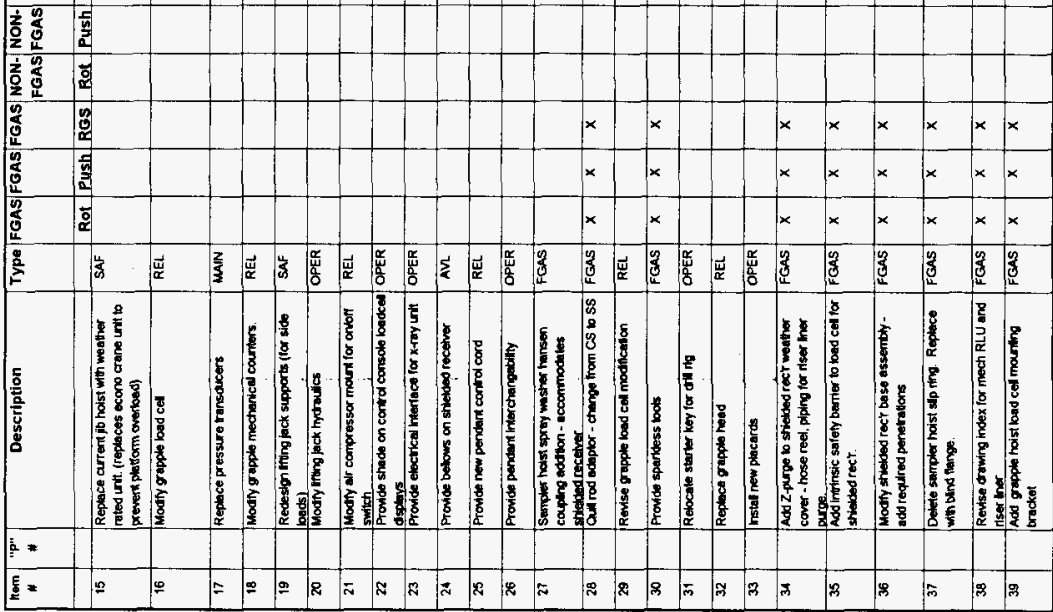




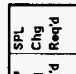

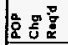

$\frac{1}{2}$

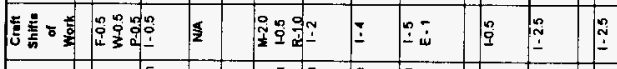

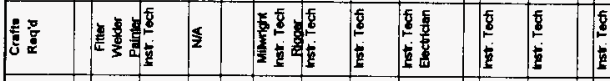

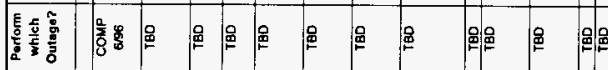

崑总

If

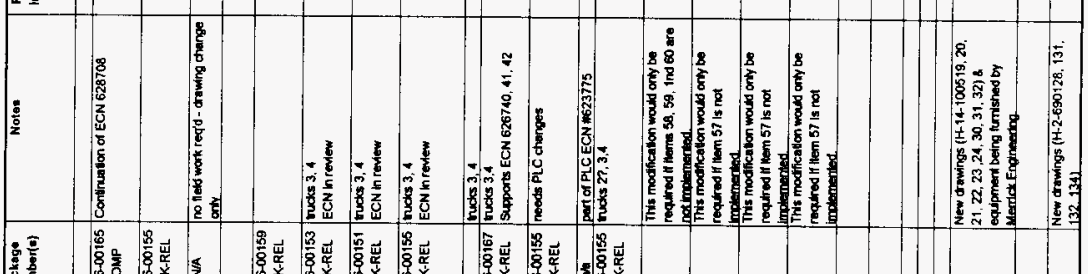

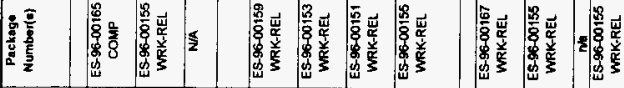

* 偦

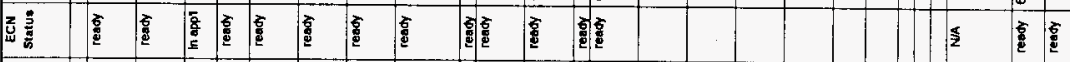

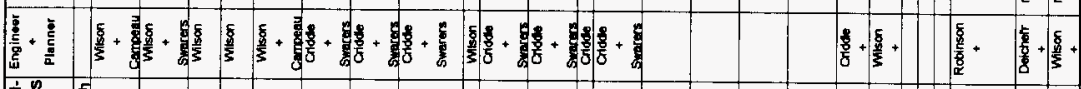

\begin{tabular}{|c|c|c|c|c|c|c|c|c|c|c|c|c|c|c|c|c|c|c|}
\hline 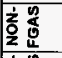 & & & & $x$ & & & & x & $\alpha$ & & & & & & & & & $x$ \\
\hline 章产 & 훙 & & & $x$ & & & & $x$ & k & $x$ & & & & & & & & $x$ \\
\hline$\frac{2}{3}$ & 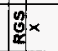 & $x$ & $x$ & $x$ & x & $x$ & x & $x$ & x & $x$ & $x$ & $x$ & $x$ & $x$ & & & x & $x \times$ \\
\hline 1 & 站 & $x$ & $\times$ & $x$ & x & $x$ & $\times$ & $x$ & $x$ & $k$ & & & & & & & $x$ & $x \times$ \\
\hline 18 & 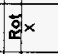 & $x$ & $x$ & $\times$ & $x$ & $x$ & $x$ & $x$ & $x$ & $x$ & & & & & & & $x$ & $\times x$ \\
\hline & 爱 & 整 & $\frac{2}{3}$ & $\frac{2}{3}$ & $\frac{y}{2}$ & $\frac{y}{3}$ & $\frac{y}{3}$ & 跑 & $\frac{3}{3}$ & 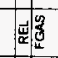 & $\frac{8}{4}$ & $\frac{3}{3}$ & 㴔 & 称 & $\frac{2}{3}$ & & $\xi$ & $\frac{3}{3} / \frac{\xi}{2}$ \\
\hline & 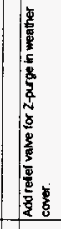 & 曾 & 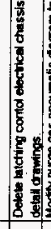 & & & & $\frac{8}{2}$ & 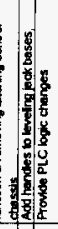 & $\frac{8}{4}$ & 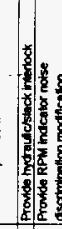 & $\frac{5}{\frac{5}{2}}$ & & 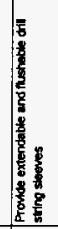 & 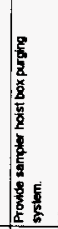 & 橲 & & 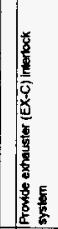 & 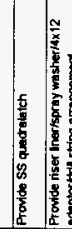 \\
\hline & & & & & & & & & & & & & & & & & & \\
\hline & $q$ & $=$ & $\approx F$ & & $\%$ & $1 \%$ & $=$ & $\% \%$ & 8 & 50 & $\pi$ & $\$$ & 8 & & $=8$ & & & $\sim m$ \\
\hline
\end{tabular}




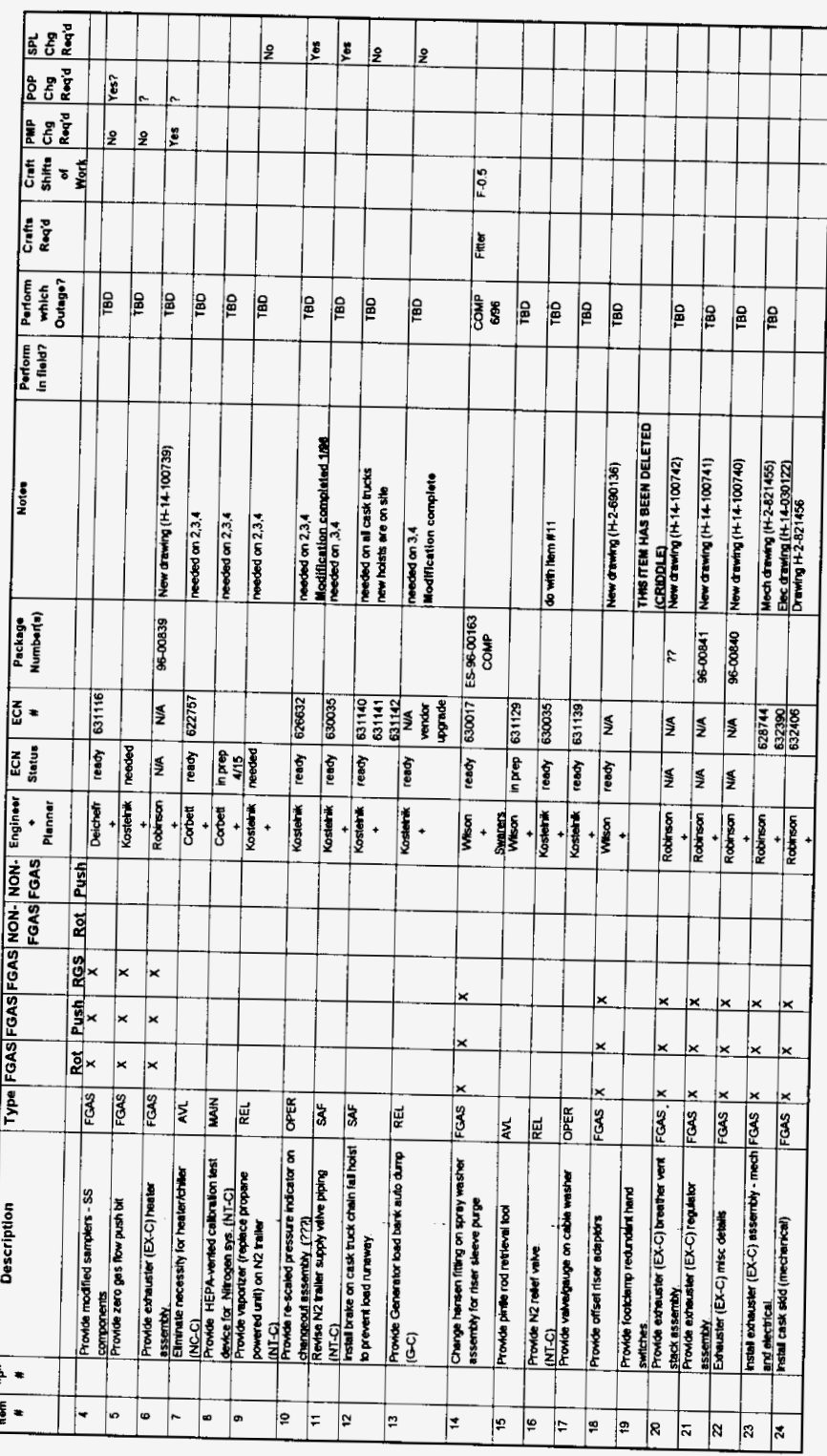




\begin{tabular}{|c|c|c|c|c|c|c|c|c|c|c|c|c|c|}
\hline $\begin{array}{l}\text { Problem } \\
\text { Identity }\end{array}$ & & & & Equip & Problem Description & $\begin{array}{l}\text { Prio } \\
\text { nity }\end{array}$ & \begin{tabular}{|l|} 
Org. \\
Resp.
\end{tabular} & Cause of Problem & $\begin{array}{l}\text { Action Taken or } \\
\text { Required }\end{array}$ & $\begin{array}{l}\text { Closed } \\
\text { (date) }\end{array}$ & \begin{tabular}{l|l} 
Action \\
$\log \#$
\end{tabular} & \begin{tabular}{|l|} 
Work \\
Priority \\
\end{tabular} & Individual \\
\hline Entry & Sys. & $\#$ & $\log$ & \# & & & & & & & & & \\
\hline & & & & & & & & & & & & & \\
\hline $960401 \mathrm{~A}$ & TS2 & 3 & E/O & & Problems with fast rotation, would not kick in & & Maint & & Adjusted limit switch & $4 / 1 / 96$ & & & \\
\hline $960401 \mathrm{~A}$ & TS2 & 1 & $\mathrm{E}$ & & $\begin{array}{l}\text { Need to cut approx } 1 " \text { of anti-rotations bracket - it currently hits } \\
\text { the bottom of the bellows assembly }\end{array}$ & & Maint & Wrong bolt?? & ES-96-00102 & & & & \\
\hline $960401 \mathrm{~A}$ & TS2 & 6 & o & & Mechanical \& electrical counters for RLU not working right & & Maint & & ES-96-00102 & $4 / 1 / 96$ & & & \\
\hline $960401 \mathrm{~A}$ & TS2 & 7 & 10 & & Ram pressure up gage cracked & & Maint & & ES-96-00221 & $4 / 1 / 96$ & & & \\
\hline $960401 \mathrm{~A}$ & TS2 & 2 & $\mathrm{E}$ & & Unintended platform rotation & & Des & & & $4 / 1 / 96$ & & & \\
\hline $960401 \mathrm{~A}$ & TS2 & 4 & E/O & & When HBD was tested, rams did not reverse very quickly & & Maint & & & $4 / 1 / 96$ & & & \\
\hline $960401 \mathrm{~A}$ & TS2 & 5 & $\mathrm{E} / \mathrm{O}$ & & Instrument cabinet sun shield not secured properly & & Maint & & & $4 / 1 / 96$ & & & \\
\hline $960401 \mathrm{~B}$ & TS1 & 1 & 0 & & Jib Hoist wires on truck shorted out & & Maint & & & & & & \\
\hline $960401 \mathrm{C}$ & TS2 & 1 & $E$ & & $\begin{array}{l}\text { While trying to remove the grapple head, shaft was over torqued } \\
\text { and failed }\end{array}$ & & Maint & & & & & & \\
\hline $960401 \mathrm{~J}$ & TS2 & 1 & $\mathrm{~J}$ & & $\begin{array}{l}\text { Compressor not hard wired into truck, pressure guage does not } \\
\text { work }\end{array}$ & & Maint & & ES-96-00218 & Yes & & & \\
\hline $960401 \mathrm{~J}$ & TS4 & 2. & $J$ & & TS\&R bellows & & Maint & & ES-96-00224 & $4 / 1 / 96$ & & & \\
\hline $960401 \mathrm{~J}$ & TS2 & 3 & $\mathrm{~J}$ & & Compacitor on compressor needs to be replaced & & Maint & & ES-96-00225 & & & & \\
\hline $960401 \mathrm{~J}$ & TS2 & 4 & $\mathrm{~J}$ & & Repkace grapple head with new strenghthened head & & Maint & & ES-96-00226 & $4 / 3 / 96$ & & & \\
\hline $960401 \mathrm{~J}$ & & 5 & $j$ & & Replace grapple head with new strenghthened head & & Maint & & ES-96-00227 & & & & \\
\hline $960401 \mathrm{j}$ & TS4 & 6 & $\mathrm{~J}$ & & Mddify grapple hoist drum to prevent bird's nesting & & Maint & & ES-96-00228 & & & & \\
\hline $960401 \mathrm{~J}$ & & 7. & $\mathrm{~J}$ & & Replace grapple head with new strenghthened head & & Maint & & ES-96-00230 & Yes & & & \\
\hline $960401 \mathrm{~J}$ & TS2 & 3. & $J$ & & Furge gas control valve is leaking internally & & Maint & & Replaced valve & $4 / 196$ & & & \\
\hline $960401 \mathrm{~J}$ & TS2 & 1 & $\mathrm{~J}$ & & Thermostat on drum heater not working & & Maint & & & $4 / 196$ & & & \\
\hline $960401 \mathrm{~J}$ & TS2 & 2 & 1 & & Slow rotation ramp time to be adjusted down & & Maint & & & $4 / 1 / 96$ & & & \\
\hline $960402 \mathrm{~B}$ & TS2 & 1 & $E$ & & New problem with fast rotation & & Maint & & & & & & \\
\hline $960402 \mathrm{~J}$ & & 1. & J & & Temperature gauge on nitrogen trailer is broken & & Maint & & ES-96-00231 & Yes & & & \\
\hline $960402 \mathrm{~J}$ & TS2 & 1 & $\mathbf{J}$ & & $\begin{array}{l}\text { No-shok gauge has cracked glass } \\
\text { Hytraulic reservoir is low } \\
\text { Thermostat on drum heater not working } \\
\text { Sampler hoist counter drifting from zero } \\
\text { Slo-ro ramp time to be adjusted down } \\
\text { Center light won't come on } \\
\text { Puige gas control valve-is leaking internally-. }\end{array}$ & & Maint & & ES-96-00232 & $4 / 4 / 96$ & & & \\
\hline $960402 \mathrm{~J}$ & TS2 & 2 & $\mathrm{~J}$ & & 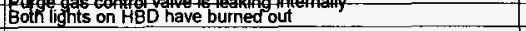 & & Maint & & ES-96-00235 & $4 / 2 / 96$ & & & \\
\hline $960402 \mathrm{~J}$ & TS2 & 3 & $\mathrm{j}$ & & Unable to initiate fast rotation - suspect proportional control valve & & Maint & & ES-96-00240 & $4 / 3 / 96$ & & & \\
\hline $960403 \mathrm{~A}$ & TS2 & 1 & E & & No x-ray - technician not available & & Ops & & & & & & \\
\hline $960403 \mathrm{~B}$ & TS2 & 1 & $E$ & & No x-ray (apparently couldnt make him a shade hut) & & Ops & & & & & & \\
\hline $960403 \mathrm{C}$ & TS2 & 1. & EIO & & Water pump on support truck not working & & Maint & & & & & & \\
\hline $960403 \mathrm{C}$ & TS2 & 1. & $E / O$ & & Water pump on support truck not working & & Maint & & & & & & \\
\hline $960403 \mathrm{~J}$ & TS2 & 2 & $\bar{\jmath}$ & & R/R switch for water pump on support truck & & Maint & & ES-96-00248 & 4/4/96. & & & \\
\hline $960404 \mathrm{~J}$ & TS3 & 1 & $\mathrm{j}$ & & Spray washer not working, suspect drum level switch & & Maint & & ES-96-00250 & $5 / 9 / 96$ & & & \\
\hline $960405 \mathrm{~A}$ & TS4 & 2 & $E$ & & DCl on RLU hoist is not functioning properly & & Maint & & ES-96-00254 & & & & \\
\hline $960405 \mathrm{~A}$ & TS4 & 1 & E & & Need to adjust grapple hoist loadcell & & Des & & & & & & Criddle \\
\hline $960405 \mathrm{~B}$ & TS1 & 1. & 10 & & Contamination problem inside windbreak & & Ops & & & & & & \\
\hline 9604058 & TS1 & 21 & 10 & & Longyear not running properly & & Maint & Dity gas & & & & & \\
\hline
\end{tabular}




\begin{tabular}{|c|c|c|c|c|c|c|c|c|c|c|c|c|c|}
\hline $\begin{array}{l}\text { Problem } \\
\text { Identity }\end{array}$ & & & & Equip & Problem Description & $\begin{array}{l}\text { Prio } \\
\text { rity }\end{array}$ & $\begin{array}{r}\text { Org. } \\
\text { Resp. }\end{array}$ & Cause of Problem & $\begin{array}{l}\text { Action Taken or } \\
\text { Required }\end{array}$ & $\begin{array}{l}\text { Closed } \\
\text { (date) }\end{array}$ & \begin{tabular}{l|l|} 
Action \\
Log \#
\end{tabular} & $\begin{array}{r}\text { Work } \\
\text { Priority }\end{array}$ & Individual \\
\hline Entry & Sys. & $\#$ & $\log$ & \# & & & & & & & & & \\
\hline & & & & & & & & & & & & & \\
\hline $960405 \mathrm{~J}$ & TS3 & 1 & J & & Sun screen on control console has broken hinge & & Maint & & ES-96-00255 & $5 / 24 / 96$ & & & \\
\hline $960405 \mathrm{~J}$ & TS3 & 2 & $\bar{j}$ & & Control console has leads exposed at bottom & & Maint & & ES-96-00256 & $5 / 8 / 96$ & & & \\
\hline 9604088 & TS1 & 1 & 0 & & Emply casks hot when opened ( 3 mrem/hr) & & Ops & & & & & & \\
\hline 9604088 & TS1 & 2 & 0 & & Problem with crew being hot, no air movement in windbreak & & Ops & & & & & & \\
\hline $960408 \mathrm{C}$ & TS4 & 1 & $E$ & & Grapple hoist loadcell again not working right & & Des & & ES-96-00261 (4/9) & & & & \\
\hline $960408 \mathrm{~J}$ & TS4 & 2 & $j$ & & $\begin{array}{l}\text { Speed control on sampler hoist doesn't vary speed } \\
\text { Ramp time on slow rotation way too long }\end{array}$ & & Maint & & ES-96-00259 & $4 / 8 / 96$ & & & \\
\hline 960408 & TS3 & 1 & $J$ & & $\begin{array}{l}\text { Torque converter oil low } \\
\text { Hydraulic fittings on platform need tightening }\end{array}$ & & Maint & & ES-96-00260 & $4 / 8 / 96$ & & & \\
\hline 9604081 & TS2 & 3 & $\mathrm{~J}$ & & Replace level switch on support truck & & Maint & & ES-96-00262 & $4 / 9 / 9 \overline{6}$ & & & \\
\hline $960409 \mathrm{~B}$ & TS4 & 1 & $E$ & & Bird's nest on grapple hoist & & Maint & & ES-96-00269 & Yes & & & \\
\hline $960409 \mathrm{~B}$ & TS1 & 1 & 0 & & Contamination around riser & & Ops & & & & & & \\
\hline $960409 \mathrm{~B}$ & TS1 & 2 & 0 & & Operator had 7000 counts skin contamination & & Ops & & & & & & \\
\hline $960409 \mathrm{~J}$ & TS2 & 1 & $\mathrm{~J}$ & & TS\&R RPM sensor, it is shutting down truck & & Maint & & ES-96-00263 & $4 / 9 / 96$ & & & \\
\hline $960410 \mathrm{~B}$ & TS1 & 1 & 0 & & X-ray machine could not be placed due to lack of room & & Ops & & & & & & \\
\hline $960410 \mathrm{~J}$ & & 1 & $\mathrm{~J}$ & & Water meter on spray wash pump is broken off & & Maint & & ES-96-00273 & $5 / 10 / 96$ & & & \\
\hline $960411 \mathrm{~B}$ & TS1 & 1 & o & & $\begin{array}{l}\text { Problem with contamination leaking out at threaded portion } \\
\text { where drill string and gas mitigation screw together. Only } \\
\text { happens when purging drill string with arcon. }\end{array}$ & & Des & & & & & & \\
\hline $960411 \mathrm{~J}$ & TS4 & 1. & $\mathrm{~J}$ & & Purge gas manual flow control valve leaks internally & & Maint & & ES-96-00272 & & & & \\
\hline $960411 \mathrm{~J}$ & & 2 & $\mathrm{~J}$ & & $\begin{array}{l}\text { Replace Appleton connector with Hubbell } 330 \text { connector for } \\
\text { truck air compressor cord }\end{array}$ & & Maint & & ES-96-00281 & $4 / 11 / 96$ & & & \\
\hline $960412 B$ & TS3 & 1 & $E$ & & Ram pressure gauge had hydraulic and glycol leaks & & Maint & & & & & & \\
\hline $960412 B$ & TS3 & 2 & $\mathrm{E}$ & & Inst fech cannot initialize new disk/magnetic tape for recorder & & & & & & & & \\
\hline $960412 B$ & TS4 & 1 & $\mathrm{E}$ & & Load cell readout higher today than yesterday, cause unknown & & Des & & & & & & \\
\hline $960412 \mathrm{~J}$ & & 1 & $J$ & & install the rebuilt spray washer pump & & Maint & & ES-96-00285 & $4 / 17 / 96$ & & & \\
\hline $960415 \mathrm{~A}$ & TS3 & 1 & $E / O$ & & Could not connect quill rod to drill string. & & Maint & Bushing upside down & ES-96-00286 & $4 / 15 / 96$ & & & \\
\hline 9604158 & IS1 & 1 & EfO & & Bird's nest developed & & Maint & & ES-96-00288 & $4 / 18 / 06$ & & & \\
\hline $960416 \mathrm{~A}$ & TS3 & 1 & $\mathrm{E}$ & & $\begin{array}{l}\text { RLU counts showed a couple of anomalies on first } 2 \text { segments. } \\
\text { All readings were perfect after that. }\end{array}$ & & Des & Watch & & & & & \\
\hline $960416 \mathrm{~B}$ & TS3 & 1 & $E$ & & No $x$-ray machine & & Ops & & & & & & \\
\hline $960416 \mathrm{C}$ & TS3 & 1 & E & & Blue strobe on purge gas cabinet does not flash & & Maint & & ES-96-00296 & Yes & & & \\
\hline $960416 \mathrm{C}$ & TS3 & 3 & $\bar{E}$ & & Need to reset time on VGR to daylight savings time & & Maint & & ES-96-00296 & Yes & & & \\
\hline $960416 \mathrm{C}$ & TS3 & 2 & E & & $\begin{array}{l}\text { Ramp down function for fast rotation stops abruptly and causes } \\
\text { a shock load }\end{array}$ & & Des & As designed & & $4 / 16 / 96$ & & & \\
\hline $960416 \mathrm{C}$ & TS3 & 4. & $E$ & & Noted a 'whine' in Longyear when in 'remote hydraulics' & & Des & & & & & & \\
\hline $960416 \mathrm{~J}$ & & 1 & J & & $\begin{array}{l}\text { Rewire mounting panel subassembly to correspond to wring on } \\
\text { trucks } 3 \text { and } 4 \text { (ECN } 618727 \text { ) }\end{array}$ & & Maint & & ES-96-00289 & & & & \\
\hline $960416 \mathrm{~J}$ & & 2 & J & & $X$-ray machine is contaminated and needs servicing & & Ope & & ES-96-00290 & Yes & & & \\
\hline $960417 \mathrm{~A}$ & TS3 & 1 & $E / O$ & & Instument enclosure high temp. Air conditioner not running & & Maint & & ES-96-00296 & Yes & & & \\
\hline $960417 \mathrm{~A}$ & TS3 & 2 & EIO & & Weld blew out on changeout assembly at 18 psi & & Des & Old changeout assbly & & & & & \\
\hline $960417 \mathrm{~B}$ & TS3 & 2 & $\mathrm{E}$ & & $\begin{array}{l}\text { Platform rotation not working in fast or slow from console } \\
\text { pendant. Suspect digi-valve }\end{array}$ & & Des & & $\begin{array}{l}\text { ES-96-00299 } \\
(4 / 18 / 96)\end{array}$ & & & & \\
\hline
\end{tabular}




\begin{tabular}{|c|c|c|c|c|c|c|c|c|c|c|c|c|c|}
\hline $\begin{array}{l}\text { Problem } \\
\text { Identity }\end{array}$ & & & & Equip & Problem Description & $\begin{array}{c}\text { Prio } \\
\text { rity }\end{array}$ & $\begin{array}{l}\text { Org. } \\
\text { Resp. }\end{array}$ & Cause of Problem & $\begin{array}{l}\text { Action Taken or } \\
\text { Required }\end{array}$ & $\begin{array}{l}\text { Closed } \\
\text { (date) }\end{array}$ & $\begin{array}{c}\text { Action } \\
\text { Log \# }\end{array}$ & $\begin{array}{l}\text { Work } \\
\text { Priority } \\
\end{array}$ & Individual \\
\hline Entry & Sys. & $\#$ & $\log$ & \# & & & & & & & & & \\
\hline & & & & & & & & & & & & & \\
\hline 9604178 & TS3 & 1 & E & & $\begin{array}{l}\text { High LFL in drill string. Pressurization method did not work. } \\
\text { CGM method did work, but CGM pump got contaminated }\end{array}$ & & Ops & & & & & & \\
\hline $960417 \mathrm{C}$ & TS3 & 2 & $\bar{E}$ & & Fluid leaking from torque converter an to ground & & Maint & & ES-96-00300 & Yes & & & \\
\hline $960417 \mathrm{C}$ & TS3 & 1. & E/O & & RPM reading on front DCl erratic & & Des & & & & & & \\
\hline $960417 \mathrm{~J}$ & TS3 & 1 & J & & Adjust torpedo on grapple cable & & Maint & & ES-96-00297 & Yes & & & \\
\hline $960417 \mathrm{~J}$ & TS4 & 2 & $\mathrm{~J}$ & & Adjust torpedo on grapple cable & & Maint & & ES-96-00298 & & & & \\
\hline $960418 \mathrm{~A}$ & TS3 & 1 & $E$ & & Tried every method to purge FG. None worked & & Ops & & & & & & \\
\hline $960418 \mathrm{~A}$ & TS4 & 1 & E & & $\begin{array}{l}\text { Possible leak in purge gas cabinet to upper half of change out } \\
\text { assembly }\end{array}$ & & Maint & & & & & & \\
\hline $960418 \mathrm{~B}$ & TS3 & 1. & E & & Spurious RPM alarm & & Des & & ES-96-00301 & & & & \\
\hline 960419A & TS4 & 1 & E & & Need to adjust VGR clock and need new disk in VGR & & Maint & & & & & & \\
\hline 9604198 & TS1 & 1 & E/O & & Longyear starter broke & & Maint & & & $4 / 19 / 96$ & & & \\
\hline $960419 \mathrm{~J}$ & TS3 & 2 & J & & TS\&R RPM Gauge & & Des & & ES-96-00114 & & & & \\
\hline $960419 \mathrm{~J}$ & TS3 & 1 & ᄀ & & Spurious RPM alarm & & Des & & ES-96-00303 & & & & \\
\hline $960422 \mathrm{~A}$ & TS3 & 2 & E/O & & Fast rotation not working again, slow barely working & & Des & & ES-96-00305 & Yes & & & \\
\hline $960422 \mathrm{~A}$ & TS3 & 1 & $\mathrm{E}$ & & Continuing problems with proportional control valve & & Des & & & & & & \\
\hline $960422 \mathrm{~A}$ & TS3 & 3 & $E / O$ & & Sahpler weighed -130 lbs, got stuck 3 feet up. & & Ops & & & & & & \\
\hline $960422 \mathrm{~J}$ & TS3 & 1 & J & & $\begin{array}{l}\text { Inspect sheilded receiver lifting frame for deformation, not level } \\
\text { Adjust hydraulics for lffting frame, runs extremely jerky down } \\
\text { Blue strobe not flashing }\end{array}$ & & Maint & & ES-96-00308 & $5 / 14 / 96$ & & & \\
\hline $960423 \mathrm{~A}$ & TS4 & 1 & O & & Neied nitrogen pressure adjusted in nitrogen cabinet & & Ops & & & & & & \\
\hline $960424 \mathrm{~B}$ & TS1 & 1 & $E / O$ & & $\begin{array}{l}\text { Grapple cable fouled up again, Had problems dropping the } \\
\text { pintle rod. }\end{array}$ & & Ops & $\begin{array}{l}\text { Dried waste in quill rod } \\
\text { and probably drill string }\end{array}$ & ES-96-00313 & $4 / 29 / 96$ & & & \\
\hline $960425 B$ & TS4 & 1 & $E / O$ & & $\begin{array}{l}\text { Had problems building up sufficient pressure in drill string prior } \\
\text { to unseating sampler (reached } 7 \text { psi) }\end{array}$ & & Ops & & & & & & \\
\hline $960425 \mathrm{C}$ & TS3 & 1 & E & & $\begin{array}{l}\text { Removed two pressure regulators that were recently installed } \\
\text { (platform hydraulics) }\end{array}$ & & Des & & & Yes & & & \\
\hline $960425 \mathrm{~J}$ & & 1 & $J$ & & $\begin{array}{l}\text { Cog eng wants rest of wiring checked for problems (truck } \\
\text { support equipment) }\end{array}$ & & Maint & & ES-96-00316 & 6/6/96 & & & \\
\hline $960425 \mathrm{~J}$ & TS4 & 1. & J & & Replace the flow rate controller (FC-3) & & Maint & & ES-96-00317 & $4 / 26 / 96$ & & & \\
\hline $960426 \mathrm{C}$ & TS3 & 4 & E/O & & Ptatform rotation could not be achieved & & Des & Digi-valve acting up & ES-96-00321 & $4 / 29 / 96$ & & & \\
\hline $960426 \mathrm{C}$ & TS3 & 1 & E & & No $x$-ray taken - mentioned several times this core & & Ops & & & & & & \\
\hline $960426 \mathrm{C}$ & TS3 & 2. & $\mathrm{E}$ & & Are there any plans to add a quick disconnect to quill rod? & & Des. & & & & & & \\
\hline $960426 \mathrm{C}$ & TS3 & 3 & $E$ & & May have leak in purge gas piping system & & Maint & & & & & & \\
\hline $960429 \mathrm{~A}$ & TS3 & 1 & $E / 0$ & & Pulled up quadralatch without sampler & & Des & & & & & & \\
\hline $960429 \mathrm{~B}$ & TS3 & $1:$ & E'O & & TS\&R ram hydraulics, rams are drifting down & & Maint & & ES-96-00323 & $4 / 29 / 96$ & & & \\
\hline $960430 \mathrm{~A}$ & TS3 & 1 & E & & $\begin{array}{l}\text { Design - why do we have a } 20 \text { psi deadband for cycling the } \\
\text { walkdown function? } 10 \text { psi would speed the process }\end{array}$ & & Des & & & & & & \\
\hline $960501 \mathrm{~J}$ & & 1 & J & & Replace broken cap on distribution trailer with truck \#3 & & Main & & ES-96-00332 & $6 / 4 / 96$ & & & \\
\hline $960502 \mathrm{~B}$ & TS 1 & 1 & 0 & & Drill string CALCULATIONS incorrect in PROCEDURE & & Field & & & & & & \\
\hline $960503 \mathrm{~B}$ & TS 1 & 1 & 0 & & Not enough people assigned for removing/installing DS & & Ops & & & & & & \\
\hline
\end{tabular}




\begin{tabular}{|c|c|c|c|c|c|c|c|c|c|c|c|c|c|}
\hline $\begin{array}{l}\text { Probiem } \\
\text { Identity }\end{array}$ & & & & Equip & Problem Description & \begin{tabular}{|l|l} 
Prio \\
rity \\
\end{tabular} & $\begin{array}{c}\text { Org: } \\
\text { Resp. }\end{array}$ & Cause of Problem & $\begin{array}{l}\text { Action Taken or } \\
\text { Required }\end{array}$ & $\begin{array}{l}\text { Closed } \\
\text { (date) }\end{array}$ & $\begin{array}{l}\text { Action } \\
\log \#\end{array}$ & $\begin{array}{r}\text { Work } \\
\text { Priority } \\
\end{array}$ & Individual \\
\hline Entry & Sys. & $\#$ & $\log$ & $\#$ & & & & & & & & & \\
\hline & & & & & & & & & & & & & \\
\hline $960503 \mathrm{~B}$ & TS4 & 1 & $E$ & & $\begin{array}{l}\text { GRAPPLE COUNTER was not always turning - missing counts } \\
\text { on way up and down. - Inspection showed grapple side of } 90 \\
\text { degree drive would tum while shaft on counter side would not. }\end{array}$ & & Maint & & & & & & \\
\hline $960503 \mathrm{~B}$ & TS1 & 2 & $E$ & & $\begin{array}{l}\text { The combo of LONGYEAR and DIAMOND DRILL may be } \\
\text { causing SAMPLERS to stick }\end{array}$ & & Des & & & & & & \\
\hline $960503 \mathrm{~B}$ & TS1 & 3 & $E$ & & $\begin{array}{l}\text { PISTON of SAMPLER got pushed up before ready to start } \\
\text { segment }\end{array}$ & & Ops & & & & & & \\
\hline $960506 \mathrm{~B}$ & TS1 & 1 & $E / O$ & & $\begin{array}{l}\text { Loud noises when raising GRAPPLE \& PINTLE. Apparent } \\
\text { hangups at QUILL ROD adaptor joint and possibly at drill string } \\
\text { joints. }\end{array}$ & & Des & & & & & & \\
\hline $960506 \mathrm{~B}$ & TS1 & 2 & 0 & & $\begin{array}{l}\text { Noises inside GRAPPLE box while raising grapple. Not } \\
\text { continuous - intermittent at various revolution counts. }\end{array}$ & & Des & & & & & & \\
\hline $960506 \mathrm{C}$ & TS2 & 1 & $E$ & & $\begin{array}{l}\text { DISTRIBUTION trailer in S-farm apparently not compatible with } \\
\text { XRAY unit. }\end{array}$ & & Maint & & & & & & \\
\hline $960506 \mathrm{~J}$ & TS3 & 1 & $\mathrm{~J}$ & & $\begin{array}{l}\text { Over pressurization may have caused PT-B, PT-9 and PG-4 to } \\
\text { malfunction or go out of calibration }\end{array}$ & & Main & & ES-96-00353 & $5 / 6 / 96$ & & & \\
\hline $960507 \mathrm{~B}$ & TS2 & 1 & $E$ & & $\begin{array}{l}\text { Issue with STANDARD conventions for N2, AIR, WATER, } \\
\text { PURGE (hose fittings) - Did not sign packages. }\end{array}$ & & Des & & & & & & \\
\hline $960507 \mathrm{C}$ & TS3 & 1 & $E$ & & $\begin{array}{l}\text { Troublshooting RAM hydraulics - Pressure Reducing Valve } \\
\text { (PRV) for lower ram not funtioning property. }\end{array}$ & & Maint & & & & & & \\
\hline $960507 \mathrm{C}$ & TS3 & 2 & $E$ & & $\begin{array}{l}\text { No SPARES for RAM PRV. - Need higher priority given to a } \\
\text { spare parts program that works. }\end{array}$ & & Maint & & & & & & \\
\hline $960507 \mathrm{~J}$ & & 1 & 3 & & Rear door struts on all N2 trailers have failed & & Main & & ES-96-00356 & $5 / 23 / 96$ & & & \\
\hline $960508 \mathrm{~B}$ & TS1 & 1 & 0 & & $\begin{array}{l}\text { Inspection of GRAPPLE box revealed that when pulling PINTLE } \\
\text { rod, reel, shafls, couplers go out of round (bend?) }\end{array}$ & & Des & & & & & & \\
\hline $960508 \mathrm{~B}$ & TS1 & 1 & $\bar{E}$ & & $\begin{array}{l}\text { Grapple drum wobbled on shaft - need to reduce clearance from } \\
0.021^{\prime \prime} \text { to } 0.005^{\prime \prime}\end{array}$ & & Des & & & & & & \\
\hline $960508 \bar{B}$ & TS1 & 2 & $E$ & & $\begin{array}{l}\text { Grapple cable should start on left hand side of drum rather than } \\
\text { near right side, as is a right hand lay }\end{array}$ & & Des & & & & & & \\
\hline 9605088 & TS1 & 3 & $\mathrm{E}$ & & Grapple cable should start on the drum taper rather than top & & Des & & & & & & \\
\hline $960508 \mathrm{C}$ & TS3 & 1 & $E$ & & $\begin{array}{l}\text { Minor problem with RAMs tending to drop on their own about } \\
1 / 2 \text {. Will cause interference problem during TRAVERSE }\end{array}$ & & Maint & & & & & & \\
\hline $960508 \mathrm{C}$ & TS3 & $\overline{2}$ & $E$ & & $\begin{array}{l}\text { Minor problem with SR sometimes "jumping" at top of travel due } \\
\text { to accumulators in system. }\end{array}$ & & Maint & & & & & & \\
\hline $960508 \mathrm{~J}$ & & 1 & $\mathrm{~J}$ & & Service trailer at U-farm breaker panel is missing 2 blanks & & Main & & $E \bar{S}-96-00368$ & & & & \\
\hline $960509 \mathrm{~A}$ & TS3 & 1 & $E$ & & RAMs still sinking, HYDRAULICS jerky. & & Maint & & & & & & \\
\hline $960509 \mathrm{~A}$ & TS3 & 2 & E & & PENDANT conrol stopped working - worked fine after lunch. & & Maint & & & & & & \\
\hline $960509 \mathrm{~A}$ & TS3 & 3 & $E$ & & $\begin{array}{l}\text { GRAPPLE motor squeaking when PINTLE rod dropped on } \\
\text { each segment. }\end{array}$ & & Maint & & & & & & \\
\hline $960509 \mathrm{C}$ & TS3 & 1 & E/O & & High flammable gas - $11 \% \mathrm{LFL}$ & & Ops & & & & & & \\
\hline $960509 \mathrm{~J}$ & TS3 & 1 & $\mathrm{~J}$ & & Accumulators A\&B may not be properly charged & & Main & & ES-96-00370 & $5 / 29 / 96$ & & & \\
\hline $960510 \mathrm{C}$ & TS3 & 1 & $E / O$ & & Broken purge gas pressure reducer gage & & Main & & & & & & \\
\hline $960510 \mathrm{C}$ & TS3 & 2 & 0 & & $\begin{array}{l}\text { Should rebend piping for clearance between PR dial and lexan } \\
\text { screen }\end{array}$ & & Main & & & & & & \\
\hline
\end{tabular}




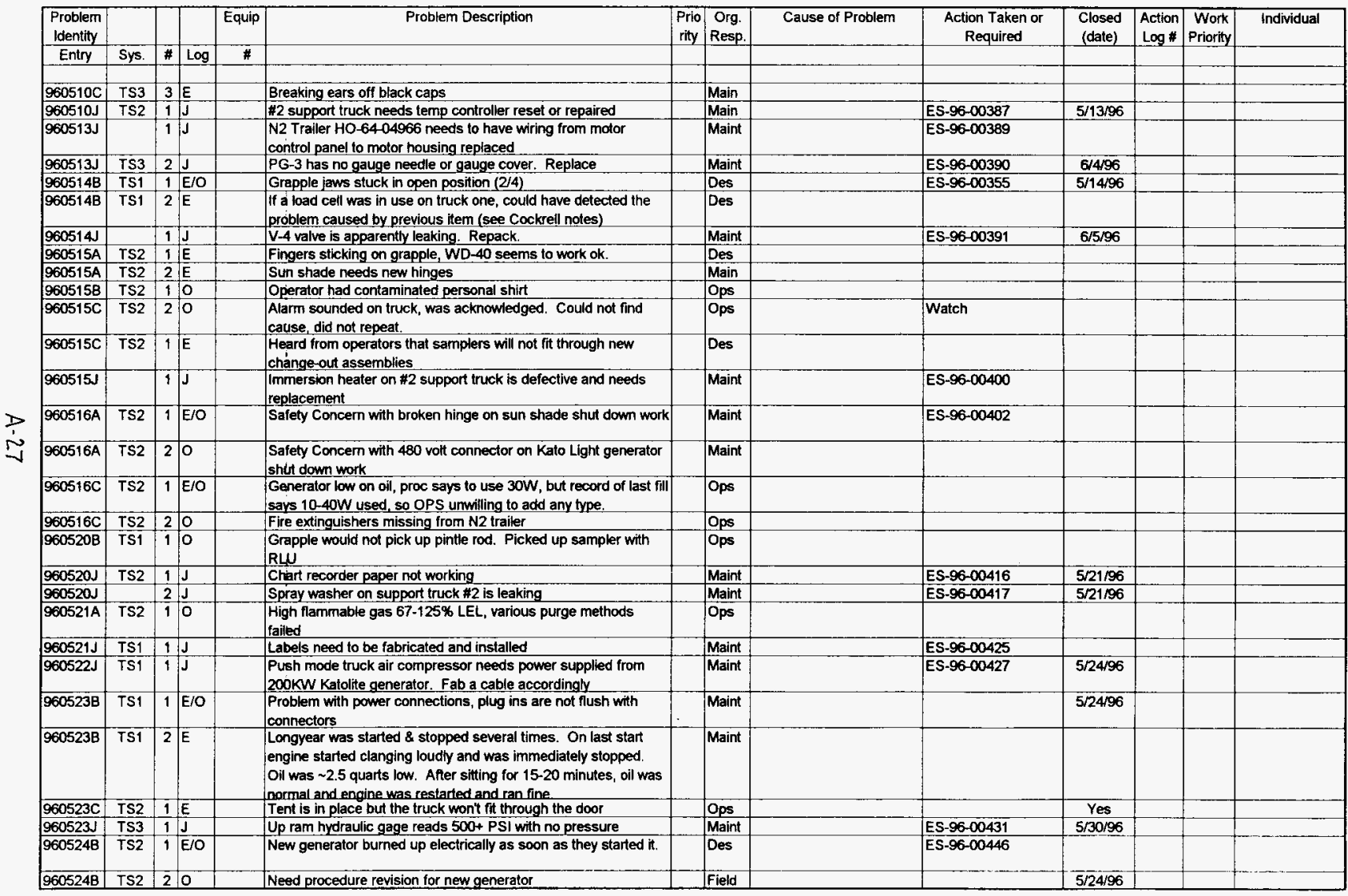




\begin{tabular}{|c|c|c|c|c|c|c|c|c|c|c|c|c|c|}
\hline $\begin{array}{l}\text { Problem } \\
\text { Identity }\end{array}$ & & & & Equip & Problem Description & $\begin{array}{c}\text { Prio } \\
\text { rity }\end{array}$ & $\begin{array}{c}\text { Org. } \\
\text { Resp. }\end{array}$ & Cause of Probiem & $\begin{array}{l}\text { Action Taken or } \\
\text { Required }\end{array}$ & $\begin{array}{l}\text { Closed } \\
\text { (date) }\end{array}$ & $\begin{array}{l}\text { Action } \\
\log \#\end{array}$ & \begin{tabular}{r|r|} 
Work \\
Priority
\end{tabular} & Individual \\
\hline Entry & Sys. & $\#$ & $\log$ & $\#$ & & & & & & & & & \\
\hline & & & & & & & & & & & & & \\
\hline $960524 \mathrm{C}$ & TS2 & 1 & 0 & & $\begin{array}{l}\text { Operator had to stop grapple motor as slack cable interiock did } \\
\text { not work }\end{array}$ & & Ops & & Watch & & & & \\
\hline $960524 \mathrm{C}$ & TS2 & 2 & 0 & & RLU did not retrieve sampler, cable stopped moving & & Des & & & & & & \\
\hline $960524 \mathrm{~N}$ & TS4 & 1 & J & & Hydraulic cylinder on the left rear jack assembly is leaking & & Maint & & ES-96-00434 & & & & \\
\hline $960528 \mathrm{~B}$ & TS2 & 1 & $E$ & & Bird's Nest in RLU & & Des & & WS-96-00193 & $5 / 31 / 96$ & & & \\
\hline $960528 \mathrm{~B}$ & TS3 & 1. & $\bar{E}$ & & $\begin{array}{l}\text { Hydraulic maintenance ongoing. Replacement of gage, } \\
\text { transducers \& pressure regulator planned }\end{array}$ & & Maint & & & & & & \\
\hline $960529 \mathrm{~B}$ & TS1 & 1. & 0 & & Truck to garage to clean out Longyear gas tank & & Maint & & & & & & \\
\hline 960529. & TS3 & 1. & J & & VGR to RF modem cable is not working correctly & & Maint & & ES-96-00451 & & & & \\
\hline $960530 \mathrm{C}$ & TS2 & 1 & 0 & & $\begin{array}{l}\text { During post RLU testing, found gross leak around shaft seal on } \\
\text { slip-ring side. }\end{array}$ & & Maint & & & & & & \\
\hline $960530 \mathrm{C}$ & TS3 & 1 & $E$ & & Continued maintenance on $R L U$ & & Maint & & & & & & \\
\hline $960530 \mathrm{~J}$ & TS1 & 1 & J & & $\begin{array}{l}\text { Power cord insulation showed signs of being damaged through } \\
\text { the insulation }\end{array}$ & & Maint & & ES-96-00456 & $6 / 4 / 96$ & & & \\
\hline $960530 \mathrm{~J}$ & & 2 & J & & $\begin{array}{l}\text { Cannon plug on power cord for distribution truck } \$ 4 \text { needs to be } \\
\text { replaced }\end{array}$ & & Des & & ES-96-00457 & $6 / \overline{5 / 96}$ & & & Daniels \\
\hline 9606038 & TS3 & 1 & E/O & & Lower Ram Pressure gage overpressurized again & & Des & & $\begin{array}{l}\text { ES-96-00461 } \\
(6 / 4 / 96)\end{array}$ & & & & \\
\hline $960603 \mathrm{C}$ & TS3 & 1 & $E$ & & $\begin{array}{l}\text { Field requests Design put priority on ECN \& Fab of shorter QR } \\
\text { adapter end pieces }\end{array}$ & & Des & & Need NCR & & & & Wilson \\
\hline $960603 \mathrm{C}$ & TS3 & $\underline{2}$ & $E$ & & BY farm is contaminating sampling equipment & & Ops & & & & & & \\
\hline $960604 \mathrm{C}$ & TS3 & $\overline{1}$ & $\overline{\mathrm{E}}$ & & Operations reported platform rotation not functioning & & Maint & intermittent - watch & ES-96-00465 & $6 / 4 / 96$ & & & \\
\hline $960604 \mathrm{C}$ & TS3 & 2 & 0 & & Fixed the exhaust pipe that runs out of the tent. & & Maint & & & & & & \\
\hline $960604 \mathrm{C}$ & TS3 & 3 & 0 & & IHPT s found level over RWP limits and shut down job. & & Ops & & & & & & \\
\hline $960606 \mathrm{~A}$ & TS3 & 1. & $E / O$ & & Grapple hoist failed, gear reducer output shaft does not turn & & Maint & & ES-96-00473/474 & $6 / 7 / 96$ & & & \\
\hline $960607 \mathrm{~B}$ & TS4 & 1 & $E$ & & $\begin{array}{l}\text { While cannibalizing gear reducer for truck 3, the grapple free fell } \\
\text { frolm hard stop to foor, knocking black cap off QR adapter }\end{array}$ & & Maint & & & & & & \\
\hline $960610 \mathrm{~A}$ & TS1 & 1. & $E / O$ & & RLU would not go into the drill string. Tube out of plumb. & & Maint & & ES-96-00479 & $6 / 10 / 96$ & & & \\
\hline 9606118 & TS1. & 1. & $E$ & & Work package to adjust travel speed of shielded receiver & & Maint & & ES-96-00482 & $6 / 12 / 96$ & & & \\
\hline $960612 \mathrm{C}$ & TS1 & 1 & $\bar{E}$ & & Air sampler broke. & & Ops & & & & & & \\
\hline $960612 \mathrm{C}$ & TS1 & 2 & E/O & & Onan generator was not level and leaked fuel on ground & & Ops & & & & & & \\
\hline $960612 \mathrm{C}$ & TS1 & 3 & $E / O$ & & Shielded receiver was not moving smoothly. & & Maint & & & & & & \\
\hline $960613 \mathrm{~B}$ & TS2 & 1 & 0 & & Green drill string vent lights would not come on & & Maint & & & & & & \\
\hline $960613 \mathrm{~J}$ & & 1 & $\mathrm{~J}$ & & Slip rings need to be changed and wiring changed to $\# 4$ & & Maint & & ES-96-00493 & $6 / 25 / 96$ & & & \\
\hline $960614 \mathrm{~A}$ & TS1 & 1 & $E / O$ & & High LFL levels & & Ops & & & & & & \\
\hline $960614 \mathrm{~B}$ & TS2 & 1 & E & & $\begin{array}{l}\text { Hetght of cask stand is just right so that shielded recelver ball } \\
\text { valve handle cuts into lower ram hydraulic hose }\end{array}$ & & Des & & & & & & Wilson \\
\hline $960614 \mathrm{~B}$ & TS2 & 2 & $E$ & & RLU hoist cut out at 1.7 and 1.2 while raising from cask & & Maint & & & & & & \\
\hline $960614 \mathrm{~B}$ & $\bar{T} \overline{2}$ & 3 & 0 & & Need to adjust downiforce so can get to 3900 \# & & Maint & & & & & & \\
\hline $960614 \mathrm{C}$ & TS1 & 2 & EIO & & Truck failed to rotate & & Maint & broken coupler & ES-96-00499 & $6 / 17 / 96$ & & & \\
\hline $960614 \mathrm{C}$ & TS1 & 1 & $\mathrm{E} / \mathrm{O}$ & & RLU came up without sampler & & Ops & & & & & & \\
\hline $960614 \mathrm{C}$ & TS1 & 3 & o & & Onan generator low oil pressure shut down generator & & Maint & & & & & & \\
\hline $960618 \mathrm{C}$ & TS1 & 1 & O & & Bit was half way unscrewed when core barrel removed & & Ops & & & & & & \\
\hline $960618 \mathrm{~J}$ & TS1 & 1. & J & & Grapple slack cable did not cut out motor & & Maint & & ES-96-00505 & $7 / 12 / 96$ & & & \\
\hline $960618 \mathrm{~J}$ & TS1 & 2. & $\mathrm{~J}$ & & Outer surface of conduit between LS-21 \& JB-9 is cracked & & Maint & & ES-96-00512 & & & & \\
\hline
\end{tabular}

Page 6 
COMBOLOG.XLS

\begin{tabular}{|c|c|c|c|c|c|c|c|c|c|c|c|c|c|}
\hline $\begin{array}{l}\text { Problem } \\
\text { identity }\end{array}$ & & & & Equip & Problem Description & $\begin{array}{l}\text { Prio } \\
\text { rity }\end{array}$ & \begin{tabular}{|c|} 
Org. \\
Resp.
\end{tabular} & Cause of Problem & $\begin{array}{l}\text { Action Taken or } \\
\text { Required }\end{array}$ & $\begin{array}{l}\text { Closed } \\
\text { (date) }\end{array}$ & $\begin{array}{l}\text { Action } \\
\log \#\end{array}$ & $\begin{array}{l}\text { Work } \\
\text { Prionity }\end{array}$ & Individual \\
\hline Entry & Sys. & \# & $\log$ & \# & & & & & & & & & \\
\hline & & & & & & & & & & & & & \\
\hline $960619 \mathrm{C}$ & TS2 & 1 & $E / O$ & & Platform hoist pendant is broken & & Maint & & & & & & \\
\hline $960619 \mathrm{C}$ & TS2 & 2 & o & & Wash pump fitting is leaking & & Maint & & & & & & \\
\hline $960619 \mathrm{~J}$ & TS2 & 1. & $\mathrm{~J}$ & & Install weather cover on the shielded receiver & & Maint & & ES-96-00525 & $6 / 20 / 96$ & & & \\
\hline $960620 \mathrm{C}$ & TS3 & 1 & E & & $\begin{array}{l}\text { Grapple weight } 29 \# \text { at top. Only goes down to } 10 \text { "when slack } \\
\text { so slack detector not functioning (set point of } 8.9 \# \text { ) }\end{array}$ & & Des & & & & & & \\
\hline $960620 \mathrm{~J}$ & TS2 & 1 & $J$ & & $\begin{array}{l}\text { Manual/remote hydraulics switch is broken } \\
\text { Hinged cover on } 110 V \text { outlet on control console is broken } \\
\text { Bottom hinge mount nut on safety gate is missing }\end{array}$ & & Maint & & ES-96-00527 & & & & \\
\hline $960621 B$ & TS2 & 1 & $\bar{E} / O$ & & Shielded receiver lifting frame not square, ram strokes differ & & Maint & & ES-96-00535 & $6 / 21 / 96$ & & & \\
\hline $960621 \mathrm{~B}$ & TS2 & 2 & E/O & & $\begin{array}{l}\text { Hydraulic pump could not be warmed up sufficiently to get } \\
\text { pressure below } 250 \text { psig. }\end{array}$ & & Ops & & & & & & \\
\hline $960621 \mathrm{C}$ & T\$2 & 2 & 0 & & Bent ball valve handle $\&$ stem on SR & & Maint & & ES-96-00544 & & & & \\
\hline $960621 \mathrm{C}$ & TS2 & 1 & O & & XRI not functioning & & Maint & & & & & & \\
\hline $960621 \mathrm{~J}$ & & 1. & $\mathrm{~J}$ & & Freeze connector on spray washer needs replacement & & Maint & & ES-96-00531 & $6 / 26 / 96$ & & & \\
\hline $960624 \mathrm{~J}$ & TS3 & -1 & J & & Grapple load cell calibration & & Maint & & ES-96-00537 & $6 / 28 / 96$ & & & \\
\hline $960624 \mathrm{~J}$ & $\overline{\mathrm{T}} \mathrm{S2}$ & 2 & $\mathbf{J}$ & & Fast rotation \& traverse do not work on control console & & Maint & & ES-96-00538 & & & & \\
\hline $960625 \mathrm{~A}$ & TS1 & 1 & $\mathbf{E}$ & & Hydraulic boltom detector not functioning properly & & Maint & & ES-96-00541 & $6 / 25 / 96$ & & & \\
\hline $960625 \mathrm{~A}$ & TS2 & 1 & $\mathbf{E}$ & & Strip chart recorder is not working. & & Maint & & & & & & \\
\hline $960625 \mathrm{~B}$ & TS2 & 1 & $\mathbf{E}$ & & Purge gas pressure refusing to hold during sample & & Ops & & & & & & \\
\hline $960626 \mathrm{~A}$ & TS1 & 1 & $E$ & & No X-ray Tech available & & Ops & & & & & & \\
\hline $960626 \mathrm{~B}$ & TS1 & 2 & $\mathrm{E}$ & & Pressure switch on the truck air compressor went out & & Maint & & ES-96-00547 & & & & \\
\hline $960626 \mathrm{~B}$ & TS2 & 1 & $\mathrm{E}$ & & $\begin{array}{l}\text { RLU slack cable weight was too close to interlock setpoint. } \\
\text { Motor was kicking on and off. }\end{array}$ & & Maint & & ES-96-00548 & & & & \\
\hline $960626 \mathrm{~B}$ & TS1 & 1 & $\mathbf{E}$ & & CGM went out & & Ops & & & & & & \\
\hline $960626 \mathrm{~B}$ & TS1 & 3 & E/O & & Compressed air regulator on foot clamp went out & & Maint & & & & & & \\
\hline $960628 B$ & TS3 & 1 & $\mathrm{E}$ & & Ops worked on grapple loadcell & & Maint & & ES-96-00558 & $6 / 28 / 96$ & & & \\
\hline
\end{tabular}




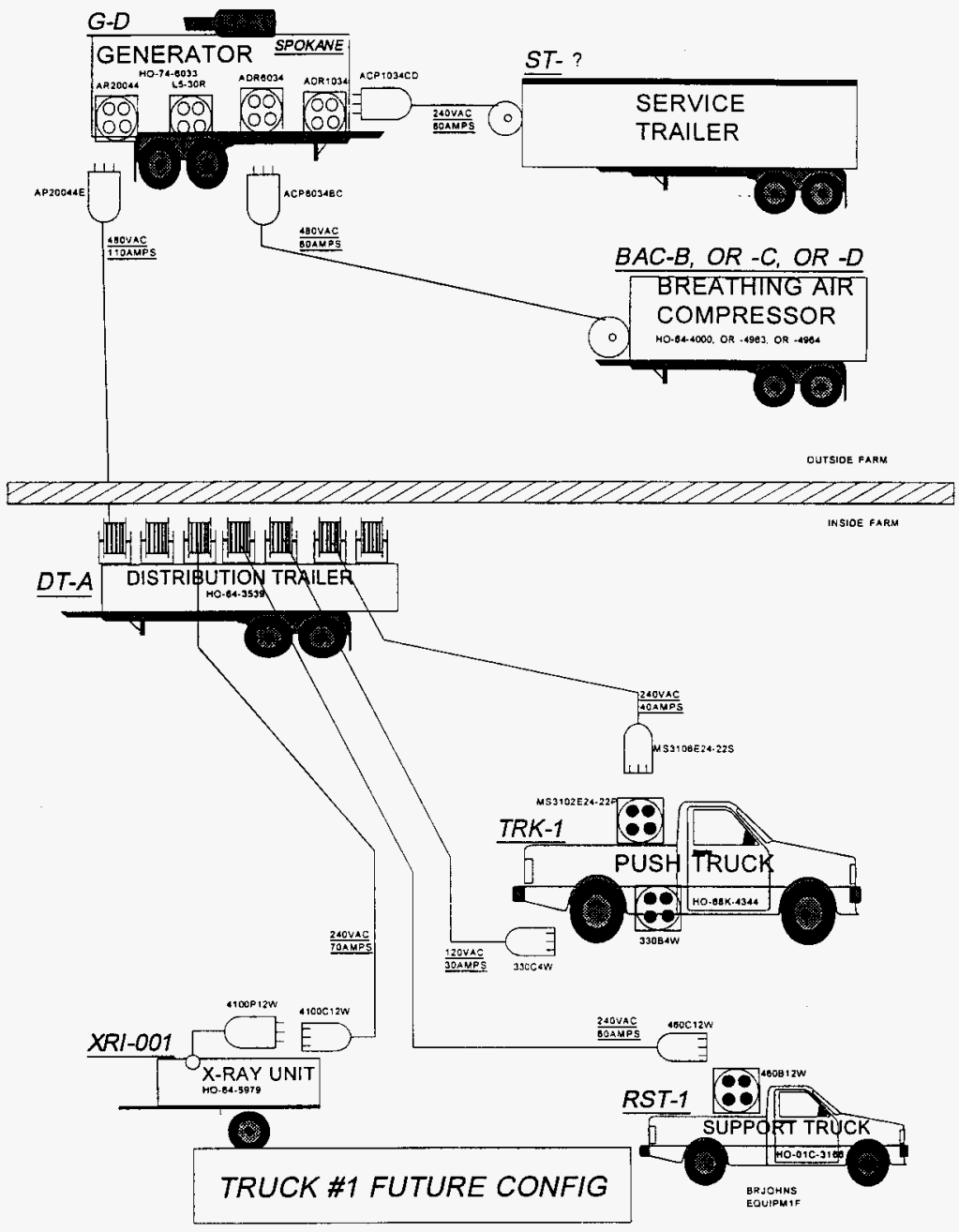




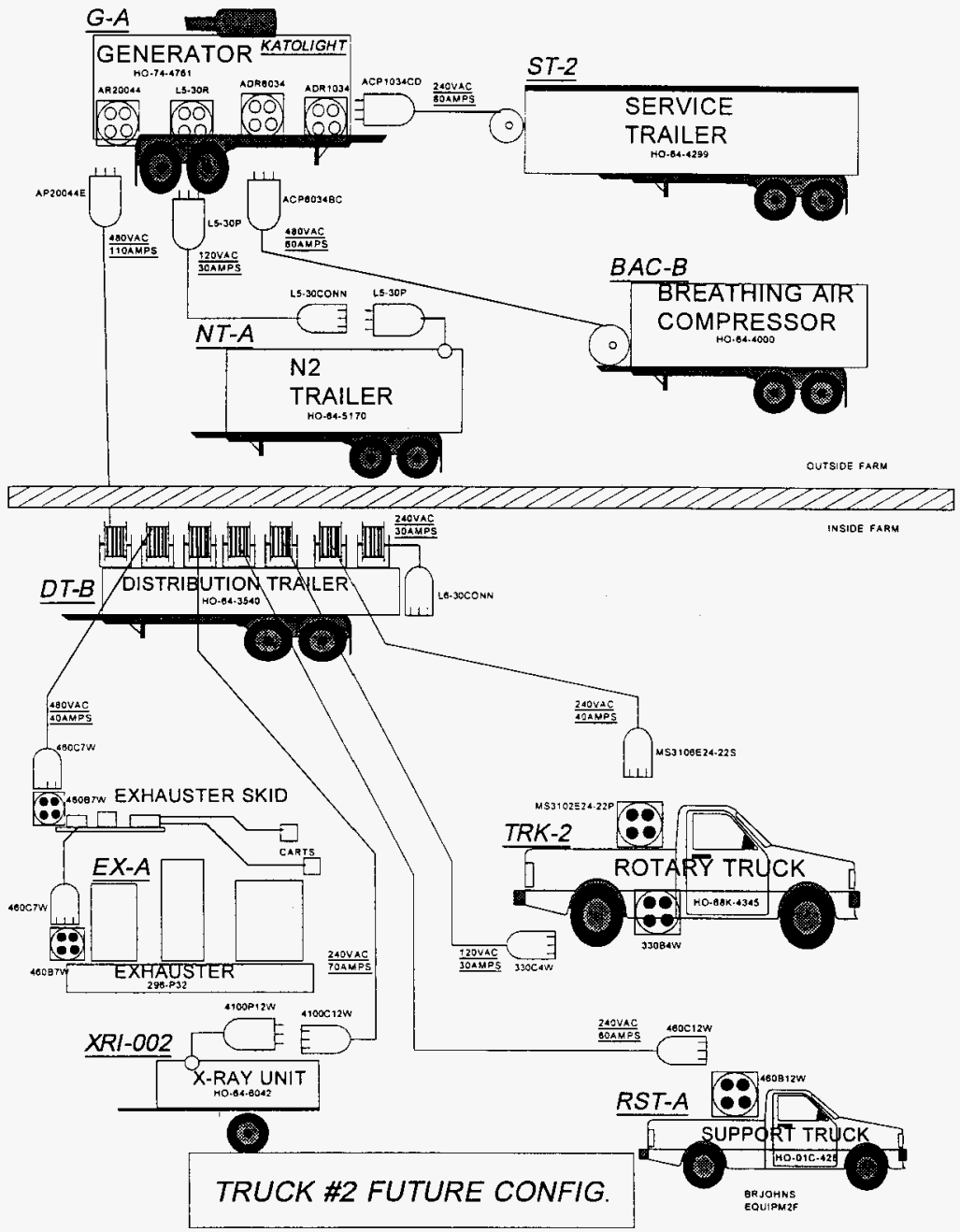




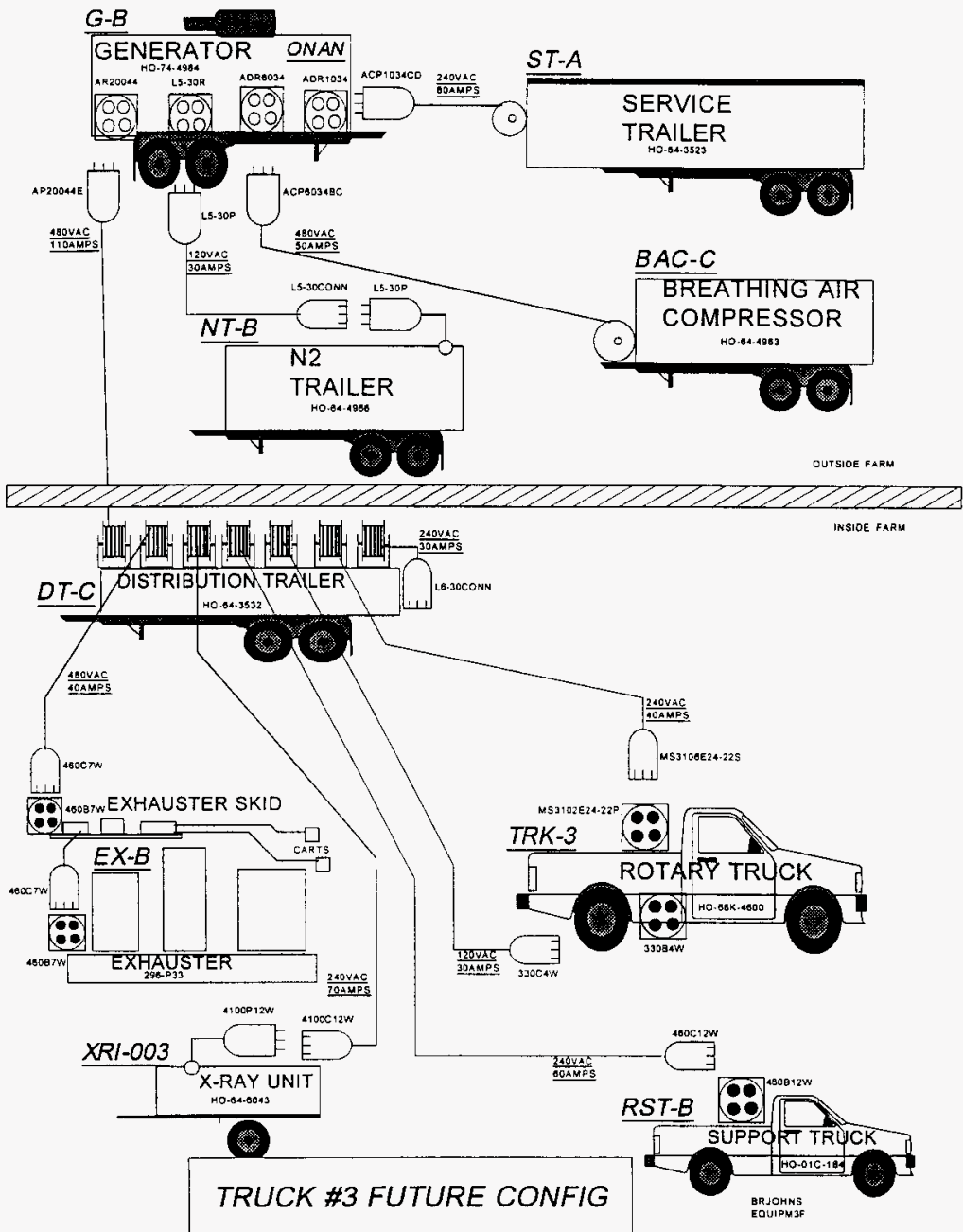




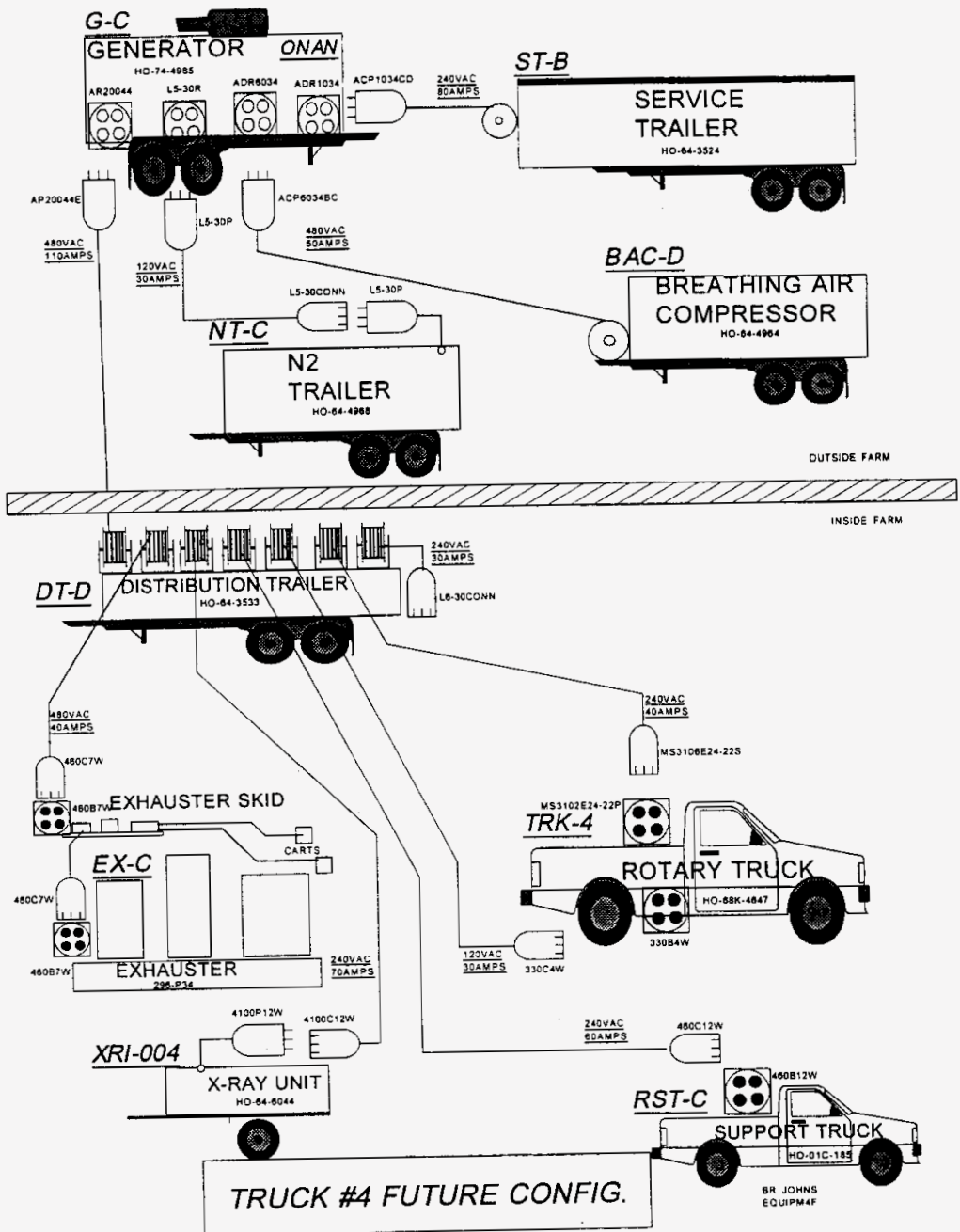




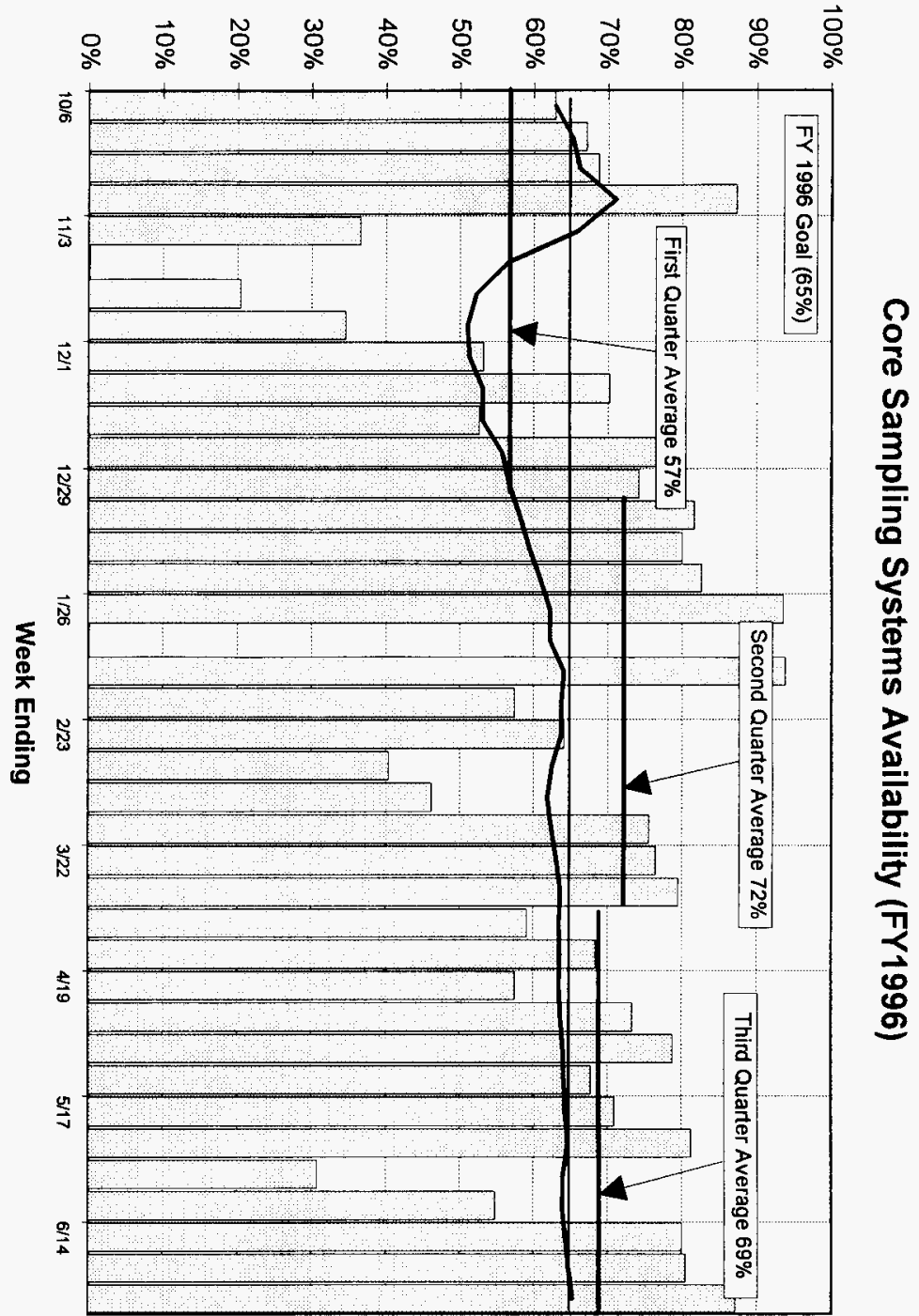




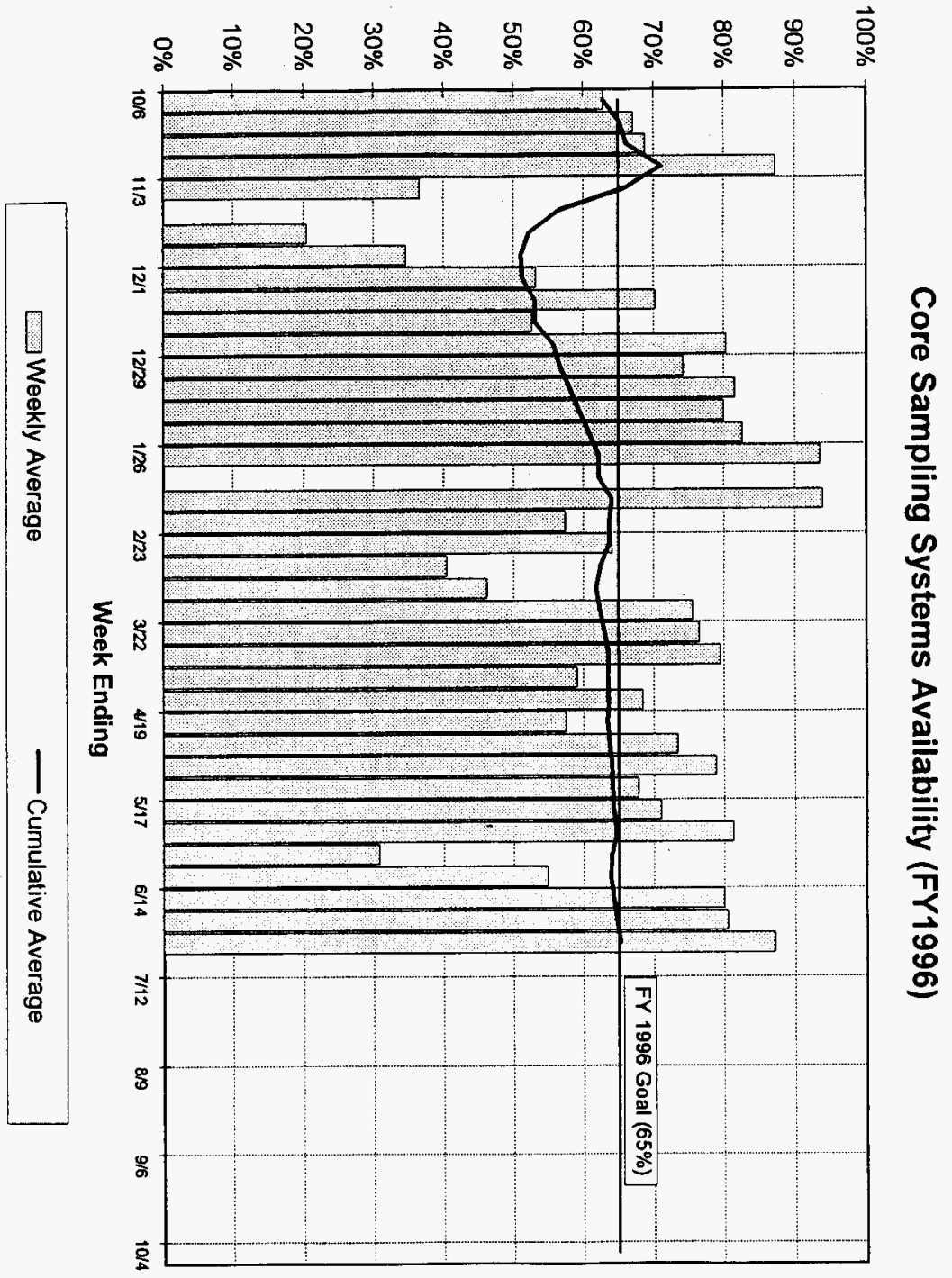




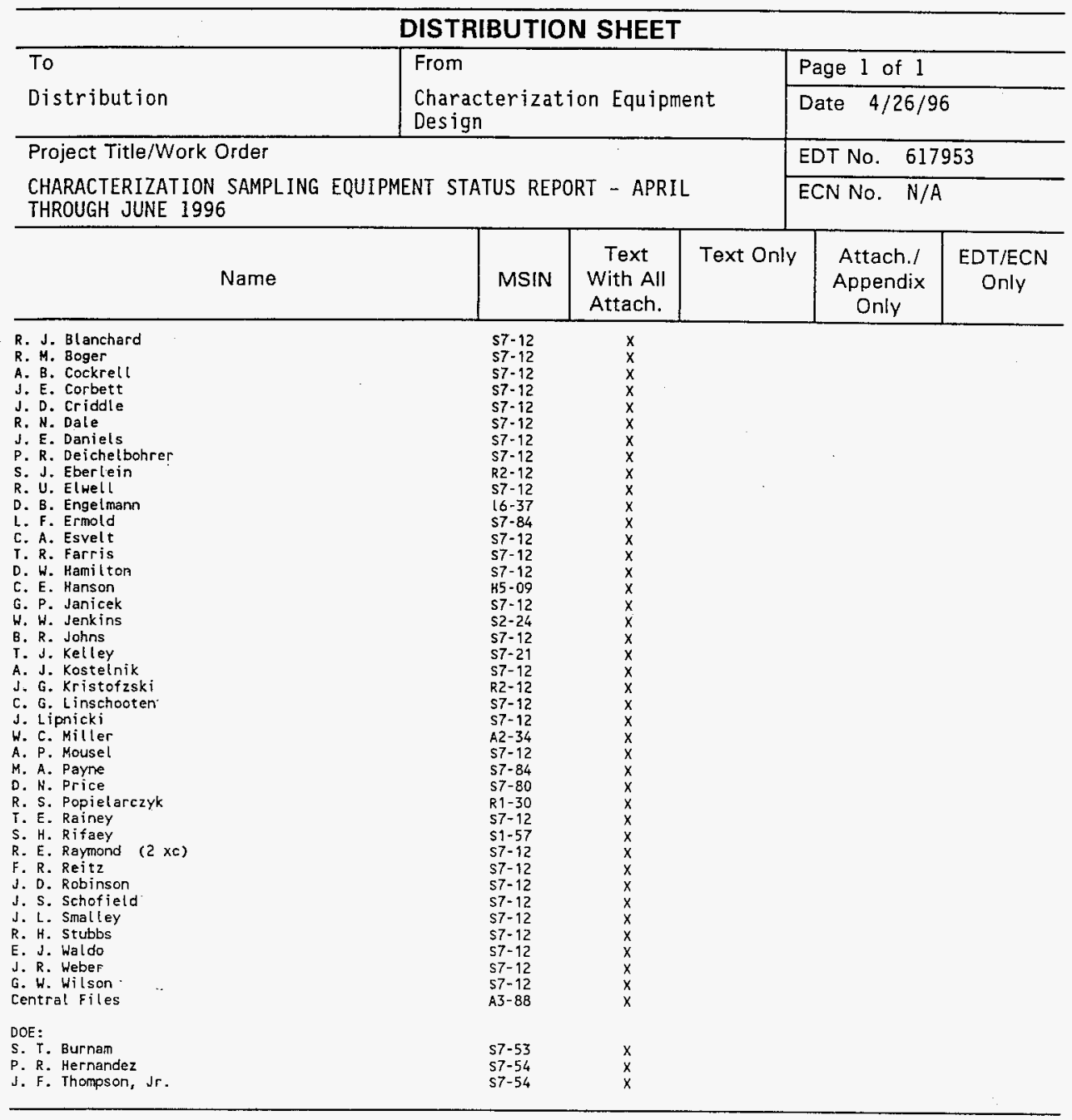

